\title{
WATER AGE IN STORMWATER MANAGEMENT PONDS AND STORMWATER MANAGEMENT POND TREATED CATCHMENTS
}

by

\author{
Kayla Wong \\ Honours BA, McMaster University, 2017
}

\author{
A thesis \\ presented to Ryerson University \\ In partial fulfillment of \\ the requirements for the degree of \\ Master of Applied Science \\ In the program of \\ Environmental Applied Science and Management
}

Toronto, Ontario, Canada, 2019

(c) Kayla Wong, 2019 


\section{Author's Declaration}

\section{AUTHOR'S DECLARATION FOR ELECTRONIC SUBMISSION OF A THESIS}

I hereby declare that I am the sole author of this thesis. This is a true copy of the thesis, including any required final revisions, as accepted by my examiners.

I authorize Ryerson University to lend this thesis to other institutions or individuals for the purpose of scholarly research.

I further authorize Ryerson University to reproduce this thesis by photocopying or by other means, in total or in part, at the request of other institutions or individuals for the purpose of scholarly research.

I understand that my thesis may be made electronically available to the public. 
Water Age in Stormwater Management Ponds and Stormwater Management Pond Treated Catchments, Master of Applied Science, 2019

Kayla Wong, Environmental Applied Science and Management, Ryerson University

\section{Abstract}

Increasing coverage of impervious surfaces in urban waterways result in 'flashy' hydrologic responses, elevated flood risk, and degraded water quality. Stormwater management ponds (SWMPs) are engineered into urban stream networks to mitigate this response. However, little is known about how SWMPs affect hydrological transit time at the catchment scale. This study aims to examine water age in SWMPs and catchments of varying SWMP control. Grab samples of $\partial^{18} \mathrm{O}$ and $\partial^{2} \mathrm{H}$ were collected biweekly from two SWMPs and five stream sites with varying land cover and stormwater control in their catchments. The damping ratio (DR), young water fraction (Fyw) and mean transit time (MTT) by sine-wave fitting were calculated for each sampled site. SWMP inlet water was consistently older than water arriving at SWMP outlets. MTT decreased as catchments SWMP control increased. Surficial geology was found to have the greatest influence on catchment MTT. 


\section{Acknowledgements}

I would like to offer many thanks to the people who have contributed to my thesis and have supported me along the way. First and foremost, my supervisor, Dr. Claire

Oswald, who has been a source of tremendous support and encouragement throughout this work. Her insightful, encouragement, and enthusiasm for research is infectious. I have learned more about research and myself through my time working with her than I could have ever imagined, and for that I am truly grateful. This research would not be possible without her. To my committee members, Dr. Chris Wellen and Dr. Darko Joksimovic, for their insights regarding study design, consultation on analysis, and for reviewing this thesis. My lab and field partner, Wai Ying Lam, for her constructive suggestions, technical support, moral support, and companionship. Field visits were always made into a joyous event and/or a brainstorming session. Many thanks to the members of the Ryerson Watershed Hydrology and Biogeochemistry Research Group, Arsh Grewal, Krystal Siebert, Sarah Ariano, Bhaswati Mazumder, and Ela Lichtblau, for their help and support, especially Krystal Siebert and Ela Lichtblau who provided technical guidance during the early days of the project. Thank you to Ryerson University, the Yeates School of Graduate Studies, and the EnSciMan Program Council for their financial support. Finally, a special thank you to my friends and family, particularly to my parents, siblings, and fiancé, whom have loved and supported me throughout my life and academic career. 


\section{Table of Contents}

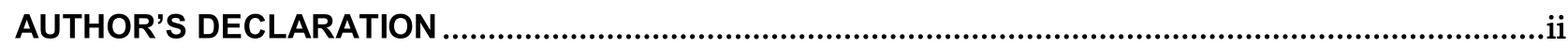

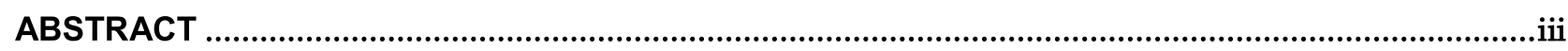

ACKNOWLEDGEMENTS …….......................................................................................................

LIST OF TABLES

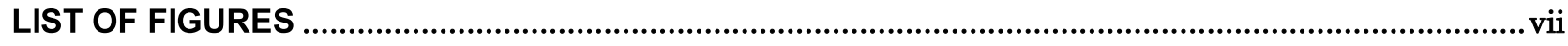

CONTRIBUTION OF AUTHORS ................................................................................................... vii

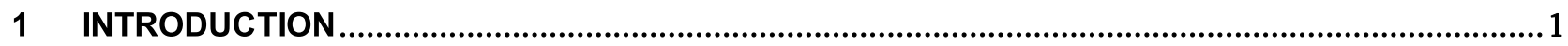

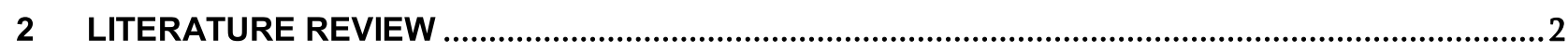

2.1 IMPACTS OF URBANIZATION ON WATER QUANTITY AND QUALITY .................................................... 3

2.2. URBan Water MANAGEMENT IN ONTARIO, CANADA ……............................................................... 5

2.3. APPLICATION OF ISOTOPE HYDROLOGY METHODS TO UNDERSTANDING CUMULATIVE IMPACTS OF StormWATER MANAGEMENT AT THE WATERSHEd SCALE ........................................................... 8

3 WATER AGE IN STORMWATER MANAGEMENT PONDS AND STORMWATER MANAGEMENT POND TREATED CATCHMENTS ................................................................................................ 11

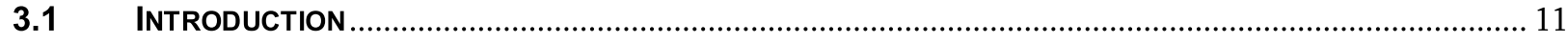

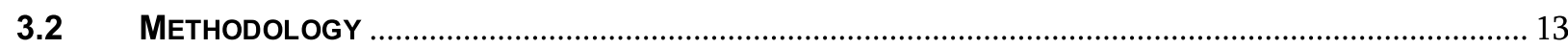

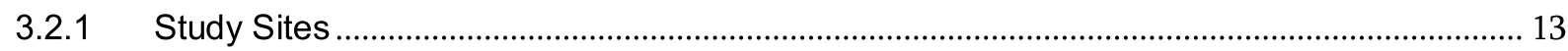

3.2.2 Landcover Distribution and Directly Connected Impervious Cover Characterization ............ 18

3.2.3 Field Sampling and Water Isotope Analysis ............................................................................ 20

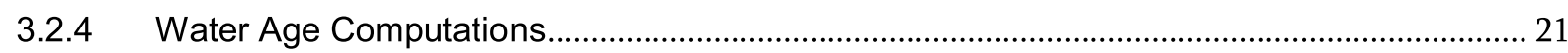

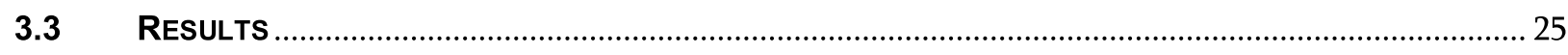

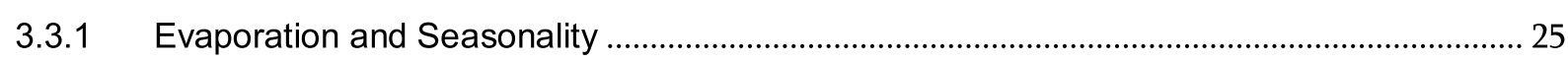

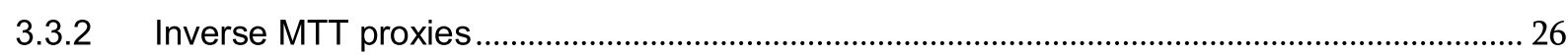

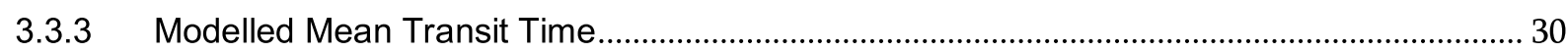

3.3.4 Comparing MTT, Fyw and DR Results in Urbanizing Catchments ......................................... 32

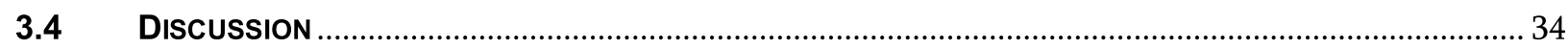

3.4.1 How does the MTT of water entering, within and exiting SWMPs compare? ........................ 34

3.4.2 Do differences in land cover and/or SWMP treatment influence catchment-scale

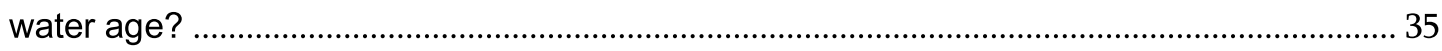

3.4.3 Do MTT, DR and Fyw have comparable results in urbanizing watersheds? ........................ 36

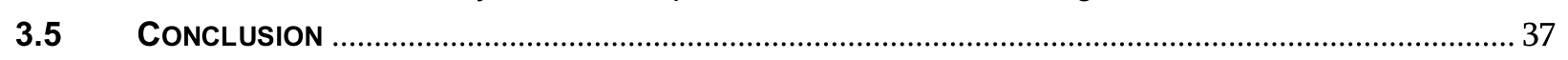

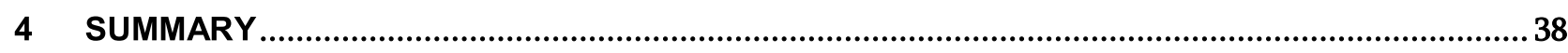

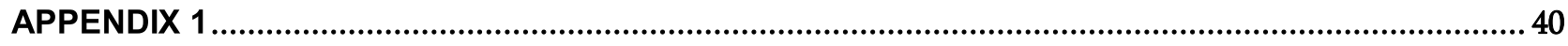

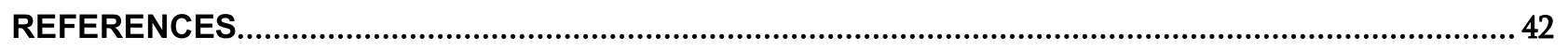




\section{List of Tables}

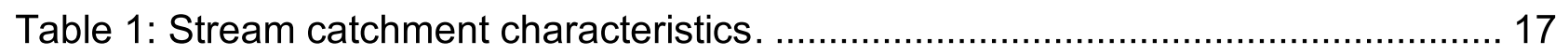

Table 2: Pond catchment characteristics................................................................... 17

Table 3: Damping ratio, young water fraction and mean transit time results. ............... 28

Table 4: Damping ratio, young water fraction and mean transit time relationships with

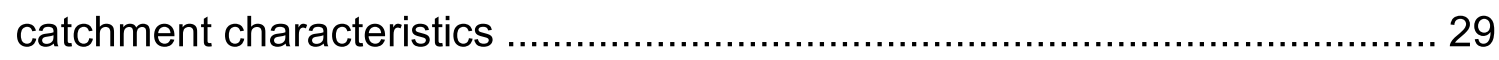




\section{List of Figures}

Figure 1: East Holland River Watershed located just south of Lake Simcoe, north of Toronto, Ontario. Stream sample sites depicted as red dots. SWMP study sites (Oak Tree and Don Hillock) represented as blue dots. Inset maps display aerial photos of studied SWMPs. SWMPs are represented in purple and the two that are studies are in blue. Terminal_EH catchment in beige, smaller studied catchment boundaries in red.

Figure 2: Catchment characteristics conceptual diagram. Impervious area represented in grey, topographic catchment boundary in purple, contributing DCIA to SWMPs boundary in dashed black outline, impervious area draining out of catchment to another SWMP outlined in orange. Storm sewers represented as a black arrow. DCIA corrected catchment area represented in grey dashed lines.

Figure 3: $\partial^{18} \mathrm{O}$ and $\partial^{2} \mathrm{H}$ sample concentrations with local (dashed) and global meteoric water lines (sold). (a) precipitation in dark blue dots, stream in light blue dots and SWMP in salmon dots. (b) precipitation as dots, stream as filled triangle and SWMP as hollow inverse triangle with fall in orange, spring in green, summer un red and winter in blue.

Figure 4: $\partial^{18} \mathrm{O}$ and $\partial^{2} \mathrm{H}$ mean transit time proxy measures with $1: 1$ line as black dashed line. (a) Damping ratio, (b) young water fraction..............................27

Figure 5: $\partial^{18} \mathrm{O}$ mean transit time relationships with catchment characteristics

Figure 6: Mean transit times (MTT) in days of studied SWMPs (a) and stream sites (b). Line $=$ mean MTT and box $=95 \%$ confidence intervals

Figure 7: Comparison of Water age metrics. Fyw, MTT and DR based on $\partial^{2} \mathrm{H}$ and $\partial^{18} \mathrm{O}$ data. Points in black, line of best fit in black dashed line.

Figure 8: Comparison of Water age metric ranks. Fyw, MTT and DR based on $\partial^{2} \mathrm{H}$ and $\partial^{18} \mathrm{O}$ data. Points in blue, line of best fit in black dashed line. $1=$ oldest water, $13=$ youngest water. 


\section{Contribution of Authors}

The manuscript included herein has two authors: Kayla Wong (Ryerson University) and Claire Oswald (Ryerson University).

K. Wong and C. Oswald contributed to the design of the study.

$\mathrm{K}$. Wong was responsible for collecting grab samples as well as consolidating the raw data.

Data analysis and interpretation were carried out by $\mathrm{K}$. Wong. Text, tables, and figures were drafted by $\mathrm{K}$. Wong and critically reviewed by $\mathrm{C}$. Oswald.

K. Wong and C. Oswald all approved of the final version to be published. 


\section{Introduction}

Urban areas around the world are growing in size, fundamentally altering natural landscapes along with the quantity and quality of freshwater running through these systems (Dunne \& Leopold, 1978; Ferrara \& Hildick-Smith, 1982; libery et al., 1982; Arnold \& Gibbons, 1996; Grimm et al., 2008). Urbanization impacts water in many ways, such as increasing runoff from impervious surfaces and increasing flood risk. As a result, urban streams are characterized by higher runoff volume, peak discharges and aquatic ecosystems (libery et al., 1982; Dunne \& Leopold, 1998; Arango et al., 2017; Liu et al., 2017; Zhou et al., 2017; Walsh et al., 2005). To mitigate this response, stormwater control measures (SCM) such as stormwater management ponds (SWMPs) are often engineered into a drainage network to slow water down (Kaushal et al., 2015). Despite the prevalent use of SWMPs as the preferred stormwater management technique (Drake \& Guo, 2008), there is a lack of information on the age (transit time) of water in SWMPs and how SWMPs affect the age (transit time) of water at the catchment scale. Understanding water transit times in watersheds impacted by urbanization is important for assessing dominant streamflow generation processes, hydrological controls on contaminant fate and transport, and potential impacts of climate change on urban water resources.

Flow pathways and hydraulic processes driving streamflow have been successfully examined in undisturbed watersheds by using isotopic hydrograph separation (Cassie et al., 1996; Burns, 2002; Huth et al., 2004; Machavaram et al., 2006; Soulsby et al., 2011; Klaus \& McDonnell, 2013) and residence/transit time 
analysis (Frederickson \& Criss, 1999; McGuire et al., 2002; McGuire et al., 2007; Tatzalff et al., 2009; Hrachowitz et al. 2016), but there are fewer examples of applying these established methods to urban watersheds (Hooper \& Shoemaker, 1986; Buttle, 1994; Burns, 2002; Soulsby et al., 2015; Parajulee et al., 2019). Although water age has been estimated in simulated SWMPs, a commonly employed stormwater management technique (Sonnenwald, Guymer \& Stovin, 2018), none have estimated water transit times in deployed and active SWMPs. The overall goal of this study is to examine water age in SWMPs and the influence that varying SWMP treated area have on water age in urban streams. Hence, the research questions of this project are: (i) What is the mean transit time (MTT) of water entering, residing in, and exiting SWMPs, (ii) how do the MTT of catchments with different land cover distributions and levels of SWMP control vary, and (iii) do different common MTT estimation methods give comparable results in urbanizing watersheds?

\section{$2 \quad$ Literature Review}

An understanding of the current state of knowledge regarding the topic of isotope hydrology in urban catchments, as it pertains to this study, will be examined in this section. The broad themes of impacts of urbanization on water quantity and quality, urban water management in Ontario, Canada, and application of isotope hydrology methods to understanding cumulative impacts of stormwater management at the watershed scale will be explored. Impacts of urbanization on water quantity and quality outlines urbanization's impact on hydrologic pathways, and pollutant and sediment transport in water. Urban water management in Ontario, Canada, follows the history of stormwater management practices in Ontario. Application of isotope hydrology methods 
to understanding cumulative impacts of stormwater management at the watershed scale looks at the development of isotope hydrology, examples of it being used at a catchment scale and the use in urban catchments.

\subsection{Impacts of Urbanization on Water Quantity and Quality}

As urban areas become more prevalent, so do their effect on the hydrology of the transformed areas. Urbanizing areas modify landcover by removing vegetation and increasing the impervious surface area, impacting the preferred hydrologic pathways of the urbanizing area (Ferrara \& Hildick-Smith, 1982; libery et al., 1982; Barbosa et al., 2012; Chang et al., 2018). This increase in urban area translates to an increase in impervious surfaces, which replaces permeable land (i.e., forests, pastures and cropland) (Saraswat et al., 2016). Impervious surfaces are non-porous surfaces which prevent water from infiltrating into the ground. These include infrastructure such as buildings, roads, sidewalks and other paved surfaces (e.g. parking-lots, playgrounds, etc.) and are indicative of an urban landscape. In a natural environment, the land is typically permeable, allowing water to infiltrate into the soil where it flows through soil's unsaturated zone to above ground waterways or recharges the groundwater storage. In urban areas, the lack of permeable surfaces leads to less infiltration of water and a significant increase in stormwater runoff (Ferrara \& Hildick-Smith, 1982; libery et al., 1982; Fry \& Maxwell, 2017). Stormwater runoff refers to water that flows over the ground during a precipitation event or snowmelt (Saraswat et al., 2016). An "event" refers to a precipitation (specifically rain fall or wet snow) or snowmelt event which would result in the urban area's "flashy" hydrologic response (i.e. high flow levels, high water levels, increase in storage volume, etc.). The increase in impervious surfaces 
changes the preferred hydrologic pathways of an area, increasing runoff rates, peak flows, and storm volumes. If unmanaged, this leads to flooding and property damage which has remained a concern for cities. In addition to the increase in impervious surfaces, a number of climate change predictions indicate that precipitation events will increase in intensity and frequency, further amplifying the increase of water quantity through stormwater (Ferrara \& Hildick-Smith, 1982; libery et al., 1982; Berndtsson, 2010; Saraswat et al., 2016).

Stormwater runoff transports large quantities of pollutants from anthropogenic activities in urban areas to receiving waterbodies (libery et al., 1982; Bachoc et al., 1994; Huang et al., 2010). The impact of rainfall dislodges particles from the surface of the ground. These particles carry pollutants that are transported by the stormwater to waterbodies via storm sewer drainage networks, stormwater channels and other urban water management infrastructure (libery et al., 1982; Barbosa et al., 2012: Zoppou, 2000). These pollutants have adverse effects on waterbodies' water quality, which can affect human health and ecologic health.

A study conducted in Finland found that stormwater runoff increased and water quality was degraded during larger precipitation events and in areas with more impervious surfaces (Metsaranta et al, 2005). These findings further support the accepted concept that the hydrology of urbanized areas, which are characterized by increased impervious areas, result in an increase in stormwater runoff and degraded water quality (libery et al., 1982; Barbosa et al., 2012: Zoppou, 2000; Berndtsson, 2010; Saraswat et al., 2016). 
The cumulative effects of SCMs at a watershed scale must be quantified to understand how small-scale stormwater practices (eg. SWMPs in urban catchments) cumulatively influence urban river health (Jefferson et al., 2017). A review paper of stormwater management network effectiveness observed an imbalance among the quantity of studies done on infiltration-based SCMs compared to detention-based SCMs, such as SWMPs. There was an abundance of literature on network effects of infiltration based SCMs and fewer studies regarding network effects of detention based SCMs (Jefferson et al., 2017). These findings further illustrate the need for a greater understanding of SWMPs' network effects.

\subsection{Urban Water Management in Ontario, Canada}

SCMs are implemented by cities to manage stormwater quality and quantity. Throughout time, our understanding of how impervious surfaces affect cities, stormwater and the environment has evolved, resulting in shifting priorities when developing and implementing SCMs.

During the 1970 s and 1980 s, the main priority of stormwater management focused on water quantity control. Flooding and water damage to infrastructure (mainly to basements) was of great concern (Ferrara \& Hildick-Smith, 1982; Smith, 1979;

OMOE, 2003). This led to the overwhelming predominance of "peak shaving" measures (e.g., SWMPs) as the prominent stormwater management technique (Ferrara \& HildickSmith, 1982). At this time dry ponds (a.k.a. detention ponds) were predominantly used to prevent flooding and prevent erosion. These ponds fill during an event and release water at a controlled rate into the receiving stream until the ponds are empty. Dry ponds are developed as "bottom draw" ponds, meaning that the outlet of the pond receives 
water from the bottom of the ponds. These were implemented in conjunction with other stormwater interventions, for example, disconnection of rooftop downspouts from city sewers. The peak shaving measures controlled the flow of stormwater and reduced peak flows so that post-development flow rates could match pre-development flow rates (Ferrara \& Hildick-Smith, 1982; OMOE, 2003; Drake and Guo, 2018). At this time, water quality was not of major concern and these measures did not require or consider sediment removal (OMOE, 2003). Attention to water quality began and was addressed in Ontario by the Great Lakes Water Quality Agreement in 1972, which commented on chemical contamination and aquatic habitat protection (OMOE, 2018). This led to the development of strategies that treated for water quality and quantity, such as retrofitting some retention basins to better address sediment buildup (Smith, 1979; Ferrara \& Hildick-Smith, 1982). However, the main priority of watershed management remained stormwater flood control under the Urban Drainage Management Program established in 1985 (Schulte-Hosteddea et al., 2007). This document was followed by the Stormwater Management Best Practices and Design Manual which was developed in 1994 and is presented as a tool for municipalities to use when deciding on a stormwater management practice to enforce at a site (OMOE, 2003). The Stormwater Management Best Practices and Design Manual was updated in 2003 (OMOE, 2003).

In the early 1990s, the impacts of pollution carried by stormwater to waterbodies became a topic of concern. Hence, the focus of stormwater management shifted from solely focusing on flood prevention to include consideration of sediment control, water temperature, nutrient loading, overall water quality and the influence of stormwater on wetlands and ecosystems (Ellis \& Marsalek, 1996; Schulte-Hostedde, 2007). At the 
same time, Low Impact Development (LID) techniques were developed. This approach to stormwater management focuses on source control by targeting stormwater at the source through hydrological functional designs while integrating pollution prevention measures. LID is a landscape-based approach to sustainable development and includes many different applications such as permeable paving, vegetated swales, grassed filter strips, green roofs, and stormwater planters (Chang et al., 2018). These strategies treat stormwater at the source by increasing the permeable surfaces in a city, thus allowing more opportunity for stormwater to directly infiltrate the soil and recharge groundwater before running off along impervious surfaces and carrying pollution (Ellis \& Marsalek, 1996; Saraswat, 2016; Chang et al., 2018). They use distributed stormwater controls, which often take the form of green infrastructure, along with green spaces to mimic the hydrologic landscape of pre-development conditions (Schulte-Hostedde, 2007; Eckart et al., 2017).

The shift in priority to include water quality, lead to the retrofitting of dry ponds and the development and implementation of wet ponds (a.k.a. retention ponds). These SWMPs, unlike dry ponds, have a set pool of water which allows sediment to settle at the bottom of the pond before water is released into the receiving stream. Wet ponds can be constructed as "bottom draw" ponds by having two bays, the forebay where sediments settle and the aftbay where the water is released at a controlled rate from the bottom of the bay. Wet ponds that are not "bottom draw" are constructed so that the pipe feeding the outlet is above the bottom of the pond at a specified height that maintains the permanent pool of water. These ponds require maintenance in the form of the removal and disposal of sediment. This responsibility is assumed by the municipality 
and is imperative for the proper functioning of these ponds (Ferrara \& Hildick-Smith, 1982; OMOE, 2003; Drake and Guo, 2018).

Presently, when addressing stormwater management, cities aim to focus on both the hydrologic system and pollution prevention to address both water quality and quantity concerns. However, due to the cost of retrofitting a developed area with LIDs, stormwater management ponds remain the prominent SCM in southern Ontario.

\subsection{Application of Isotope Hydrology Methods to Understanding}

\section{Cumulative Impacts of Stormwater Management at the Watershed Scale}

Isotope hydrology methods involve the use of residence and transit time models to analyze raw isotopic data (Tetzlaff et al., 2015; McGuire \& McDonald, 2015; Ala-Aho et al., 2017). Residence time and transit time of water is also known as the water's "age". They represent the time from water entering a catchment through precipitation to the point of collection. Residence time distribution specifically is the distribution of ages of water within the basin (from entering the catchment as precipitation). Transit time distribution is the distribution of ages of water exiting the basin (from entering the catchment as precipitation). Residence time and transit time analyses allow researchers to utilize water isotopes as tracers when studying hydrology (Tetzlaff et al., 2015).

Analysis of stable liquid water isotopes has been used since the 1960 s replacing the use of radioisotopes (e.g. tritium) to estimate the timing and magnitude of water transport through a study area (Aggarwa et al., 2007). Before the early 1960s, the focus was on the use of short-lived radio isotopes (such as tritium) as tracers in ground water systems to trace mixing characteristics, transit times and porosity (the space between 
soil particles) of the groundwater and soil. These methods were translated into use in surface water systems and at the catchment scale. Today isotope hydrology is recognized as its own discipline of hydrologic sciences with applications in small basins and hillslope hydrology. However, applications of isotope hydrology methods in urban areas are not extensive.

Hydrologists have been studying flow paths of water using isotope hydrology and hydrograph separation since the 1960s, however, these well-established methods are rarely applied in urban studies. A few studies have shown that the isotopic approach can be useful for elucidating dominant flow paths and relative rates of water storage and release in urban catchments (Buttle, 1994; Burns \& McDonnell, 1998; Burns, 2002; Jefferson et al., 2015; Parajulee et al., 2019).

Jefferson et al. (2015) used stable isotope hydrograph separation to examine the contributions of two SWMPs one wetland and one bioretention pond, to a receiving stream. The ponds had different outflow isotope signatures when compared to the inflow/event isotope signatures. This was likely a result of evaporation and mixing of different event water within the SCMs. Additionally, distinctive isotopic signatures were found for each SCM relative to the receiving stream. These findings lead the researchers to conclude that isotope hydrograph separation is a robust tool for examining stormwater-stream dynamics, which is important to further understand the impacts of SCM and the movement of water contaminants.

MTT was investigated between an urban watershed and an agricultural watershed in Toronto, Canada (Parajulee et al., 2019). The study found shorter MTTs in the urban watershed implying shorter retention in urban watersheds when compared to their 
agricultural counterparts. MTT decreased moving downstream in both watersheds, similar to another study (Soulsby et al. 2014) in Scotland that studied the transit time in an urbanizing of a watershed over a year. These studies demonstrate that stable water isotopes are useful tracers in urban watersheds. 


\section{Water Age in Stormwater Management Ponds and Stormwater Management Pond Treated Catchments}

\subsection{Introduction}

Urban areas are growing in size, fundamentally altering the natural landscape as well as the quantity and quality of freshwater (Dunne \& Leopold, 1978; Ferrara \& Hildick-Smith, 1982; libery, Foster, \& Donoghue, 1982; Arnold \& Gibbons, 1996; Grimm et al., 2008). These areas modify landcover by removing vegetation and increasing the impervious surface area, resulting in less infiltration of water and a significant increase in stormwater runoff (Ferrara \& Hildick-Smith, 1982; libery et al., 1982; Fry \& Maxwell, 2017). As a result, urban streams are characterized by higher runoff volumes, peak discharges, and higher pollutant loads when compared to their non-urban counterparts (libery et al., 1982; Barbosa, Fenandes \& David, 2012; Zoppou, 2000; Berndtsson, 2010; Saraswat, Kumar, \& Mishra, 2016). These areas are more susceptible to floods, sediment loads, chloride loads, and increasing summer stream temperatures, affecting human and ecological health (Klemetson \& Rogers, 1985; Xie \& James, 1994; James \& Verspagen, 1996; Anderson, Watt, \& Marsalek, 2002; Haq \& James, 2002; Walsh et al., 2005; Booth \& Bledsoe, 2009; Betts, Gharabaghi, \& McBean, 2014).

To mitigate these responses, stormwater control measures such as Stormwater Management Ponds (SWMPs) are often engineered into a drainage network (Kaushal et al., 2015). Storm sewers deliver surface runoff to SWMPs, which are designed as temporary reservoirs, where sediment settles to the bottom of the forebay and water is released at a controlled rate from the aftbay into a receiving stream (Kaushal \& Belt, 2012). SWMPs are designed as detention basins (a.k.a. dry ponds), where the pond fills 
during events and release water until the pond is dry, or retention basins (a.k.a. wet ponds), where the pond has a permanent pool of water and release water to a specified depth. Retention basins in Southern Ontario are lined with low permeability materials to maintain the permanent pool (Drake \& Guo, 2008). However, there is a lack of information on the age (transit time) of water as it travels through SWMPs and how these ponds affect the age (transit time) of water at the catchment scale.

Flow pathways and hydraulic processes driving streamflow have been successfully examined in undisturbed watersheds by using isotopic hydrograph separation (Cassie, Pollock, \& Cunjak, 1996; Mohammad, 1998; Burns, 2002; Huth, Leydecker, \& Sickmanet, 2004; Machavaram, Whittemore, \& Conradet, 2006; Soulsby, Piegat, Seibert, \& Tetzlaff, 2011; Klaus \& McDonnell, 2013) and residence/transit time analyses (Frederickson \& Criss, 1999; McGuire, DeWalle, \& Gburek, 2002; McGuire, Weiler, \& McDonnell, 2007; Tatzalff et al., 2009; Hrachowitz et al. 2016), but there are fewer examples of applying these established methods to urban watersheds (Hooper \& Shoemaker, 1986; Buttle, 1994; Burns, 2002; Soulsby, Birkel, Geris, \& Tetzlaff, 2015; Parajulee, Wania, \& Mitchell, 2019). Only one study has used stable isotope hydrograph separation to examine the contributions of different stormwater management techniques to receiving waterways (Jefferson, Bell, Clinton, \& Mcmillan, 2015).

While hydrograph separation has been examined for its usefulness in stormwater management plans, transit time analyses have yet to be used to study the effect that different levels of stormwater management control have on the flow pathways and water age in urban catchments. Understanding water transit times in watersheds impacted by urbanization is important for assessing dominant streamflow generation processes 
(Sidle \& Lee, 1999; Houhou et al., 2010; Jankowfsky, Branger, Braud, Gironás, \& Rodriguez, 2013; Soulsby et al., 2015; Jefferson et al., 2015), hydrological controls on contaminant fate and transport (Jankowfsky et al., 2013; Hrachowitz, Fovet, Ruiz, \& Savenije, 2015), and potential impacts of climate change on urban water resources (Ferrara \& Hildick-Smith, 1982; libery et al., 1982; Berndtsson, 2010; Saraswat et al., 2016). The combined effects of impervious surfaces that enhance surface runoff and stormwater control measures that are designed to mitigate flashy urban hydrological response are not well studied at the catchment or sub-catchment scale. Although water age has been estimated in simulated SWMPs, a commonly employed stormwater management technique (Sonnenwald, Guymer \& Stovin, 2018), none have estimated water transit times in deployed and active SWMPs. To begin to address these knowledge gaps, we sought to answer three main research questions: (i) What is the mean transit time (MTT) of water entering, within, and exiting SWMPs, (ii) how do the MTT of catchments with different land cover distributions and levels of SWMP control vary, and (iii) do different common MTT estimation methods give comparable results in urbanizing watersheds?

\subsection{Methodology}

\subsubsection{Study Sites}

This research was conducted in the East Holland River Watershed which drains north into Lake Simcoe and is located north of Toronto, Ontario, Canada (Figure 1). A $175 \mathrm{~km}^{2}$ area drains to the terminal water sampling site in the watershed (Terminal_EH; see Figure 1). It is dominated by agricultural $(35.0 \%)$ and urban (39.5\%) land cover and 
is treated by 225 SWMPs. The region experiences a mean annual precipitation of 834 $\mathrm{mm}$ and a mean annual temperature of $7.2^{\circ} \mathrm{C}$. Our study focuses on the watershed as a whole, four stream sites located along two stream reaches (Tannery Creek and the upper main branch of the East Holland River) and two SWMPs (Oak Tree and Don Hillock) (Figure 1).

\subsubsection{Stormwater Management Ponds}

The two studied SWMPs are located within the East Holland River Watershed. Oak Tree $(\mathrm{OAK})$ is a $1,851 \mathrm{~m}^{3}$ SWMP, draining a mainly residential area, and contributing water to a headwater tributary of Tannery Creek. Don Hillock (DH) is a larger 4,919 $\mathrm{m}^{3}$ SWMP, draining a mainly commercial area, and contributes to a headwater tributary of the upper main branch of East Holland River. OAK and DH are retention SWMPs (wet ponds), designed as bottom-draw, clay-lined SWMPs. In bottomdraw SWMPs the outlet of the SWMPs receive water from a channel opening at the bottom of the SWMPs' aftbays. As the name suggests, the bottom of clay-lined SWMPs are lined with clay to prevent infiltration of pond water into the ground and groundwater into the SWMP (Drake \& Guo, 2008). OAK and DH were constructed in 2004 and 2008, treating a $45,040 \mathrm{~m}^{2}$ and $166,530 \mathrm{~m}^{2}$ catchment (Table 2).

\subsubsection{Stream Sites}

Upstream and downstream sites of the two stream reaches were studied (Up_Tan, Down_Tan, Up_EH, and Down_EH). The Tannery Creek catchment resides on the south-west of the watershed and is categorized as $52 \%$ urban. Up_Tan is composed of mainly silt and clay soils (Silt and Clay $=68 \%$; Sandy Silt $=32 \%$ ) and is 
located within the Oak Ridges Moraine. Its downstream site (Down_Tan) is composed of mainly sandy silt soils (Sandy Silt $=48 \%$; Silt and Clay $=35 \%$; Gravel and Sand $=$ $17 \%)$ and only its headwater streams reside on the moraine. Most urban areas in Tannery creek's catchment are between our upstream and downstream sample points; Up_Tan's catchment is $14.2 \%$ urban and the downstream point (Down_Tan) is $52.0 \%$ urban area. Up_Tan's urban areas are treated by seven SWMPs that treat $1.8 \%$ of its $7.3 \mathrm{~km}^{2}$ catchment, while Down_Tan's urban areas are treated by 42 SWMPs that treat $52.2 \%$ of the $29.5 \mathrm{~km}^{2}$ catchment (Table 1 ).

The upper main branch of the East Holland river is mainly agricultural $(39.7 \%)$. The upstream and downstream sites are composed of mainly sandy soils (Up_EH: Silt to Silty Clay $=38 \%$, gravel and sand $=62 \%$; Down_EH: Silt to Silty Clay $=43 \%$, gravel and sand $=57 \%$ ) and reside within the moraine's borders. Up_EH and Down_EH are $20.6 \%$ and $19.8 \%$ urban and $38.4 \%$ and $39.7 \%$ agricultural, respectfully. Nine SWMPs treat $10.1 \%$ of Up_EH's $29.6 \mathrm{~km}^{2}$ catchment, while 11 SWMPs treat $8.5 \%$ of Down_EH's $36.4 \mathrm{~km}^{2}$ catchment (Table 1). 


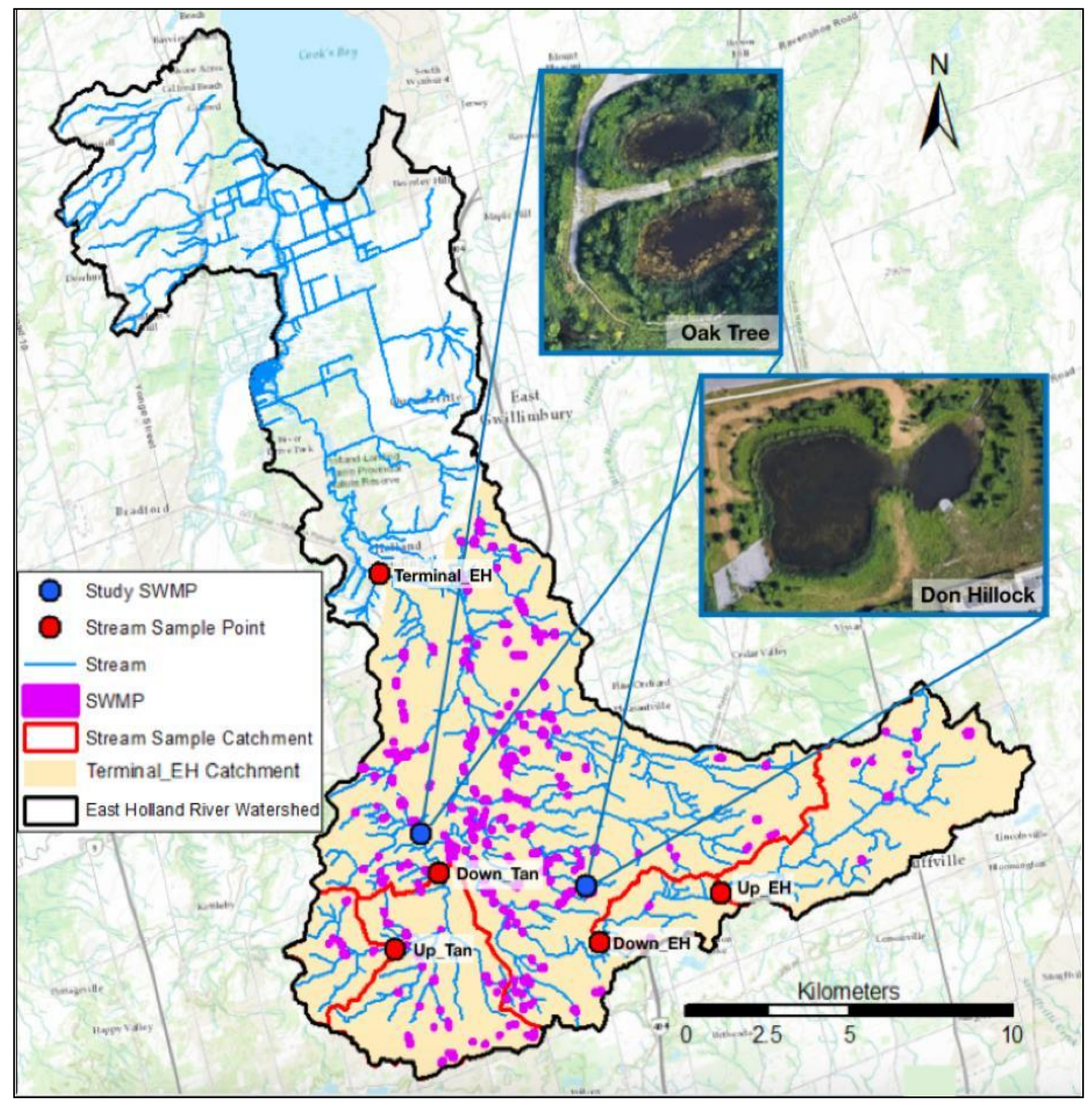

Figure 1: East Holland River Watershed located just south of Lake Simcoe, north of Toronto, Ontario. Stream sample sites depicted as red dots. SWMP study sites (Oak Tree and Don Hillock) represented as blue dots. Inset maps display aerial photos of studied SWMPS. SWMPs are represented in purple and the two that are studies are in blue. Terminal_EH catchment in beige, smaller studied catchment boundaries in red. 
Table 1: Stream catchment characteristics.

\begin{tabular}{|c|c|c|c|c|c|}
\hline & Up_Tan & Down_Tan & Up_EH & Down_EH & Terminal_EH \\
\hline $\begin{array}{l}\text { Topographic Catchment Area } \\
\qquad\left(\mathrm{km}^{2}\right)\end{array}$ & 7.3 & 29.5 & 29.6 & 36.4 & 174.6 \\
\hline $\begin{array}{c}\% \text { sandy silt or gravel and } \\
\text { sand geology }\end{array}$ & 32 & 65 & 62 & 57 & 48 \\
\hline Urban $(\%)^{*}$ & 14.2 & 52.0 & 20.6 & 19.8 & 39.5 \\
\hline Agriculture $(\%)^{*}$ & 59.7 & 27.3 & 38.4 & 39.7 & 35.0 \\
\hline Forest $(\%)^{*}$ & 7.7 & 11.6 & 20.4 & 20.1 & 18.8 \\
\hline Number of SWMPs & 7 & 42 & 9 & 11 & 266 \\
\hline Pond area $\left(\mathrm{m}^{2}\right)$ & 11,774 & 76,935 & 40,046 & 44,556 & 823,070 \\
\hline $\begin{array}{l}\text { Topographic Catchment of } \\
\text { SWMPs }(\%)^{*}\end{array}$ & 0.1 & 43.7 & 10.1 & 8.5 & 91.4 \\
\hline Total Impervious Area $(\%)^{*}$ & 0.1 & 17.8 & 4.8 & 5.2 & 15.3 \\
\hline $\operatorname{DCIA}(\%)^{\star *}$ & 1.6 & 8.3 & 3.7 & 4.0 & 8.3 \\
\hline $\begin{array}{c}\text { Treated by SWMP - DCIA } \\
\text { Corrected }(\%)^{* *}\end{array}$ & 1.8 & 52.0 & 10.1 & 8.4 & 91.4 \\
\hline
\end{tabular}

${ }^{*} \%=$ proportion of topographic catchment area.

$* * \%=$ proportion of DCIA-corrected catchment

Table 2: Pond catchment characteristics.

\begin{tabular}{|c|cc|}
\hline & Don Hillock (DH) & Oak Tree (OAK) \\
\hline Pond area $\left(\mathrm{m}^{2}\right)$ & 3724.6 & 1679.8 \\
Pond volume $\left(\mathrm{m}^{3}\right)$ & 4,919 & 1,851 \\
Topographic Catchment $\left(\mathrm{m}^{2}\right)$ & 15,714 & 5053.0 \\
DCIA $\left(\mathrm{m}^{2}\right)$ & 150,816 & 39,987 \\
DCIA Corrected SWMP Treated Catchment & $\left(\mathrm{m}^{2}\right)$ & 45,040 \\
\hline
\end{tabular}




\subsubsection{Landcover Distribution and Directly Connected Impervious Cover}

\section{$\underline{\text { Characterization }}$}

Urban catchment areas can change when the directly connected impervious area (DCIA) (the impervious areas that directly feed into a SWMP via storm sewers) is accounted for (Schmitt, Thomas, \& Ettrich, 2004; Kayembe \& Mitchell, 2018). In this study, the topographic catchment area, total impervious area (all impervious areas within the topographic catchment), the DCIA, and the DCIA-corrected catchment area were computed for each SWMP and stream site.

The digital elevation model and flow direction data (30 m x $30 \mathrm{~m}$ resolution) was obtained as part of the Ontario Integrated Hydrology Data (Ontario Ministry of the Natural Resources and Forestry, 2017) and used to delineate the topographic catchment area of each catchment. Surficial geology was determined using the Quaternary Geology of Ontario dataset (Ontario Ministry of Norther Development and Mines, 1988). The impervious area was derived in eCognition by modifying the model developed by Lichtblau \& Oswald (2019) using the 2013 GTA orthoimagery project (Ontario Ministry of the Natural Environment, 2013) and municipal building footprints as the input. Two rounds of multiresolution segmentation were performed. The first split the orthoimagery into smaller segments and the second combined the smaller segments into slightly larger ones. The shape factor set to 0.1 (emphasizes special properties) and the compactness set to 0.5 (emphasizes "compactness" and "smoothness"), the first round had a scale factor of 30 , while the second had a scale factor of 60 . The segments were then classified, using a threshold of 130 of the near infrared band were classified as "dark" (shadows, water), building footprints along with NDVI (normalized 
difference vegetation index) and BAI (built-up area index) thresholds were used to classify the vegetated and impervious areas.

Total impervious area was modelled by determining the impervious area that lies within the original topographic boundaries. DCIA was modelled by determining which sewer lines and catch basins contribute to each pond, and then which impervious areas contributed to each catch basin. This was done in the AcrGIS software environment, converting sewer networks into geometric networks and using the "Utility Network Toolbar" to determine contributing sewer lines. Pond location, area and storm sewer line data were provided by the lower- and upper-tier municipalities overlapping with the study areas. The roofs of houses were excluded from the DCIA as downspouts that drain the rooftops are disconnected from storm sewers in the study areas. The DCIA corrected SWMP treated catchment accounts for the topographic catchment plus/minus DCIA that feed into/out of the topographic catchment (Figure 2). This was done for all SWMPs within each sample location's catchment (Table 1; Table 2).

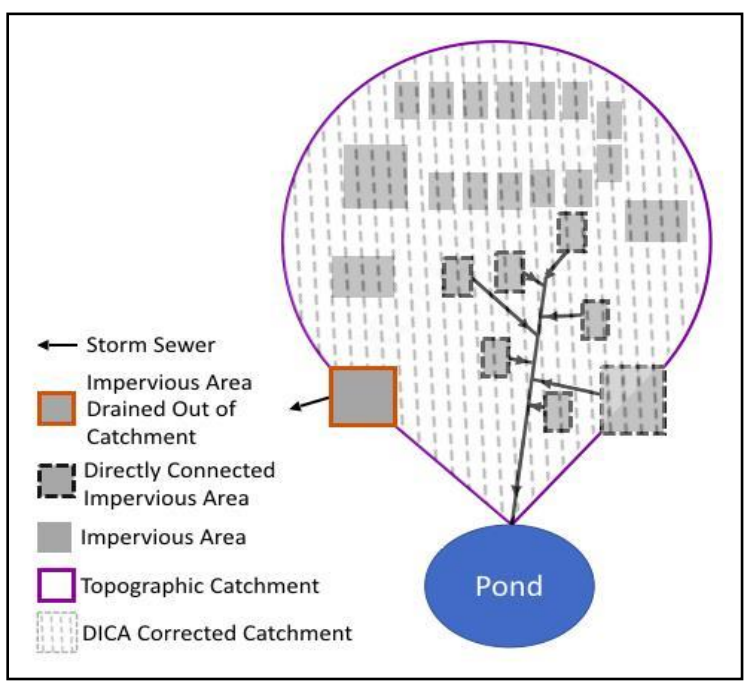

Figure 2:Catchment characteristics conceptual diagram. Impervious area represented in grey, topographic catchment boundary in purple, contributing DCIA to SWMPs boundary in dashed black outline, impervious area draining out of catchment to another SWMP 


\subsubsection{Field Sampling and Water Isotope Analysis}

Rain and stream samples were collected at Terminal_EH for just over three years (March 2016 to May 2019), while snowmelt samples were collected for one winter (November 2018 to April 2019). Stream samples at sites Up_EH, Up_Tan, Down_EH and Down_Tan were collected for two years (May 2017 to May 2019). SWMP samples were collected at the inlet, forebay, aftbay, and outlet for 1.5 years (November 2017 to May 2019). Routine samples were taken every two weeks at each site during aforementioned periods. When classifying event samples and baseflow samples, we made the assumption that event water moves quickly through our urban areas. Samples taken during an event or within 48 hours of the end of an event were classified as "event samples" and all others were classified as "base flow samples". Thus, $25 \%$ of our samples were event samples and $75 \%$ were taken during base flow conditions. High frequency sampling was also carried out at OAK's inlet, forebay, aftbay, and outlet, during one rain event (November $6^{\text {th }}, 2018$ from 8 am to $1: 15 \mathrm{pm}$ ), ensuring that the event's hydrograph rise, peak, and recession were captured. Composite rain samples were collected using a stationary funnel with a polyethylene vessel which is modified with a long thin venting tube to avoid evaporation (Li, Sugimoto, \& Ueta, 2017), while composite snowmelt was collected using a melt-pan with the dimensions of $20 \mathrm{~cm}$ wide, $30 \mathrm{~cm}$ long and $10 \mathrm{~cm}$ tall, following the design outlined in Tekeli, Sorman, Sensoy, and Şorman (2003). Upon collection samples were stored in $20 \mathrm{ml}$ high density polyethylene scintillation vials with conical polyseal caps to reduce airspace, wrapped in parafilm and stored in a dark cool place to minimize evaporation (Tetzlaff et al., 2009; Kanduč, Mori, Kocman, Stibilj, \& Grassa, 2012; Anderson et al, 2017; Garvelmann et al., 2017; Li et 
al., 2017). All samples were tested for $\partial^{18} \mathrm{O}$ and $\partial^{2} \mathrm{H}$. Samples were analyzed at the University of Manitoba, the University of Toronto Scarborough and Carleton University. Duplicates were run across labs to ensure no laboratory bias $\left(y=1.0006 x+0.705, R^{2}=\right.$ 0.9996). A relative prediction of duplicates of $2.21 \%$ and $0.88 \%$ for $\partial^{18} \mathrm{O}$ and $\partial^{2} \mathrm{H}$, respectively was observed. Delta $(\partial)$ values were recorded in permille $(\% \circ)$ deviations from the Vienna Standard Mean Ocean Water (VSMOW) (Craig, 1961).

$\partial^{18} \mathrm{O}$ and $\partial^{2} \mathrm{H}$ time series were plotted for each sample site to evaluate the dynamics of enrichment or depletion of the stable water isotopes in the stream and pond samples when compared to the $\partial^{18} \mathrm{O}$ and $\partial^{2} \mathrm{H}$ values of the precipitation. The SWMP forebay, aftbay and outlet were slightly damped when compared to the precipitation data, while the stream sites and SWMP inlets displayed stronger dampening. The $\partial^{2} \mathrm{H}$ displayed a smaller range of data when compared to the $\partial^{18} \mathrm{O}$ data, but when examined closely, the same damping patterns as $\partial^{18} \mathrm{O}$ were observed. As expected, summer samples were the most enriched for both tracers, while winter samples were the most depleted. November 2018 - January 2019 precipitation data showed a significant depletion of $\partial^{18} \mathrm{O}$ and $\partial^{2} \mathrm{H}$.

\subsubsection{Water Age Computations}

The $\partial^{18} \mathrm{O}$ and $\partial^{2} \mathrm{H}$ data were used to compute two inverse transit time proxies, the damping ratio (DR) and the young water fraction (Fyw), as well as, to estimate the mean transit-time (MTT) using sine-wave fitting. Sine wave fitting is more appropriate to use than time-based convolution modelling when sampling frequency is coarser than weekly and sometimes irregular due to intermittent flow (McGuire \& McDonnell, 2006). 
This is the case for stormwater management ponds that are specifically designed to release event water over several days. These metrics were computed within the $R$ software environment (R Core Team, 2017). The water age computations were applied using the $\partial^{18} \mathrm{O}$ and $\partial^{2} \mathrm{H}$ tracers at each sample location. The DR (Eq. 1) uses the damping of precipitation isotope signals in stream flow to characterize general trends and distributions of MTT (Tetzlaff et al., 2009; Soulsby et al., 2015; Bansah \& Ali, 2018):

$$
D R=\frac{C V o f \partial^{18} O\left(\text { or }^{2} H\right) \text { instreamflow }}{C V o f \partial^{18} O\left(o r \partial^{2} H\right) \text { inprecipitation }}
$$

where CV represents the coefficient of variation.

The Fyw was computed as outlined in Kirchner (2016a,b). We assumed that the transit time distribution $(g(\tau))$ of our sites to fall under the gamma distributions (Eq. 2) where the MTT is equivalent to the product of the shape and scale factors of the gamma distributions (Eq. 3):

$$
\begin{gathered}
g(\tau)=\frac{\tau^{\alpha-1}}{\beta^{\alpha} \Gamma}(\alpha) \exp ^{-\tau / \beta} \\
\tau=\alpha \beta
\end{gathered}
$$

where $\alpha$ and $\beta$ are the shape and scale factors of the gamma distribution, respectfully. The isotopic sinusoidal cycles of each tracer $\left(\partial^{18} \mathrm{O}\right.$ and $\left.\partial^{2} \mathrm{H}\right)$ were fitted to represent 
each site over the study period (Table A1). This was done to obtain the precipitation and site amplitudes of each cycle ( $A p$ and $A s)$. Eq. 4 illustrates the relationship between $A s$, $A p, a$ and $b$ :

$$
\frac{A s}{A p}=\left(1+(2 \pi f \beta)^{2}\right)^{-\alpha / 2}
$$

where $f$ is the frequency ( $f=1$ year- 1 for a seasonal cycle). We assumed a "young" water age threshold of three months, following Kirchner (2016a)'s recommendation which simplified Eq. 4 to Eq. 5, which was then applied to estimate the Fyw as:

$$
F y w=\frac{A s}{A p}
$$

The Fyw uncertainty calculations were then completed by running 1000 Monte Carlo simulations for $A s$ and $A p$. These simulations were then applied to Eq 5 producing 1000 Fyw results. Fyw error was determined from the upper and lower $95 \%$ confidence boundaries of the resulting Monte Carlo Fyw results.

MTT was then calculated using sine-wave fitting of $\partial^{18} \mathrm{O}$ and $\partial^{2} \mathrm{H}$ of the precipitation and sample sites over the study period (McGuire et al 2002; Tetzlaff et al., 2007) (Table A1). Sine-wave fitted lines were expressed as Eq. 6 , where $\partial$ is the fitted $\partial^{18} \mathrm{O}$ or $\partial^{2} \mathrm{H}$ value, $x$ is the sample day, $a$ is the shape factor and $b$ is the scale factor of the line. 


$$
\partial=a \sin (x)+b \cos (x)
$$

From the fitted sinusoidal cycles, the precipitation and stream amplitude can be computed as:

$$
A=\sqrt{a^{2}+b^{2}}
$$

where $A, a$ and $b$ are the amplitude, shape and scale factors of the isotopic fitted sinusoidal cycle. Once $A p$ and $A s$ are determined, the MTT $(\tau)$ in days is estimated as:

$$
\tau=\frac{1}{c} \sqrt{\left(\frac{A s}{A p}\right)^{-2}-1}
$$

where $c=0.017214 \mathrm{rad} \mathrm{d}^{-1}$ is the angular frequency constant. The uncertainty of the MTT estimates were quantified by determining the $95 \%$ confidence intervals of $\tau$. This was done by determining the $95 \%$ confidence of the fitted sine wave's $a$ and $b$ used in Eq 6 and using these bounds to run 1000 Monte Carlo simulations for $A s$ and $A p$. These simulations were then applied to Eq 8 producing 1000 MTTs. MTT error was determined from the upper and lower $95 \%$ confidence boundaries of the resulting MTTs. 


\subsection{Results}

\subsubsection{Evaporation and Seasonality}

Stream samples experienced a higher range in $\partial^{18} \mathrm{O}$ and $\partial^{2} \mathrm{H}$ values when compared to the SWMP $\partial^{18} \mathrm{O}$ and $\partial^{2} \mathrm{H}$ values $(-5.1 \%$ to $-16.5 \%$ and $-6.3 \%$ to $-14.6 \%$, respectfully) (Figure 3a). When examining samples based on season, a clear distinction can be seen between the summer $\left(\partial^{18} \mathrm{O}=-5.1 \%\right.$ to $-11.6 \%$ ) and winter $\left(\partial^{18} \mathrm{O}=-9.9 \%\right.$ to $-15.3 \%$ ). Although, the fall and spring samples overlap with all other seasons, spring samples are skewed towards higher $\partial^{18} \mathrm{O}$ and $\partial^{2} \mathrm{H}$ concentrations indicative of warmer temperatures and fall samples are skewed towards lower $\partial^{18} \mathrm{O}$ and $\partial^{2} \mathrm{H}$ concentrations, indicative of cooler temperatures (Figure 3b). Relative to the local meteoric water line, most SWMP samples experiences a positive $\partial^{18} \mathrm{O}$ shift, while some show a depletion in $\partial^{18} \mathrm{O}$. A depletion in $\partial^{18} \mathrm{O}$ can be seen in the winter, fall and spring stream samples, while all stream summer samples experienced a positive shift in $\partial^{18} \mathrm{O}$.

The evaporation and seasonality relationships observed in Figure 3 are indicative of the mid-latitude continental climate of the study site. The samples placements in the $\partial^{18} \mathrm{O}$ and $\partial^{2} \mathrm{H}$ plot relative to the local and global meteoric water line are representative of the seasonal climate, where waterways experience freezing for a significant portion of the year and evaporation is only experienced during warmer seasons. This translates to an evaporative function that is closer to the meteoric water lines than their non-seasonal counterparts (Gibson, Birks, \& Yi, 2016). The differences observed in stream and SWMP samples and in the samples taken during each season, illustrate the differences in freezing that SWMPs and streams experience. As the SWMPs experience more freezing than the stream sites and thus a more phase changes are represented in this 
analysis by depletion in $\partial^{18} \mathrm{O}$ when compared to the stream sites. It is also important to recognize that SWMPs in this region are more saline than their pre-developed waterways due to the addition of de-icing agents. Higher salt concentrations in water has been found to decrease the thermodynamic activity of the water and its evaporation rate (Gat \& Levy, 1978; Gonfiantini, 1986; Horita, 1990).

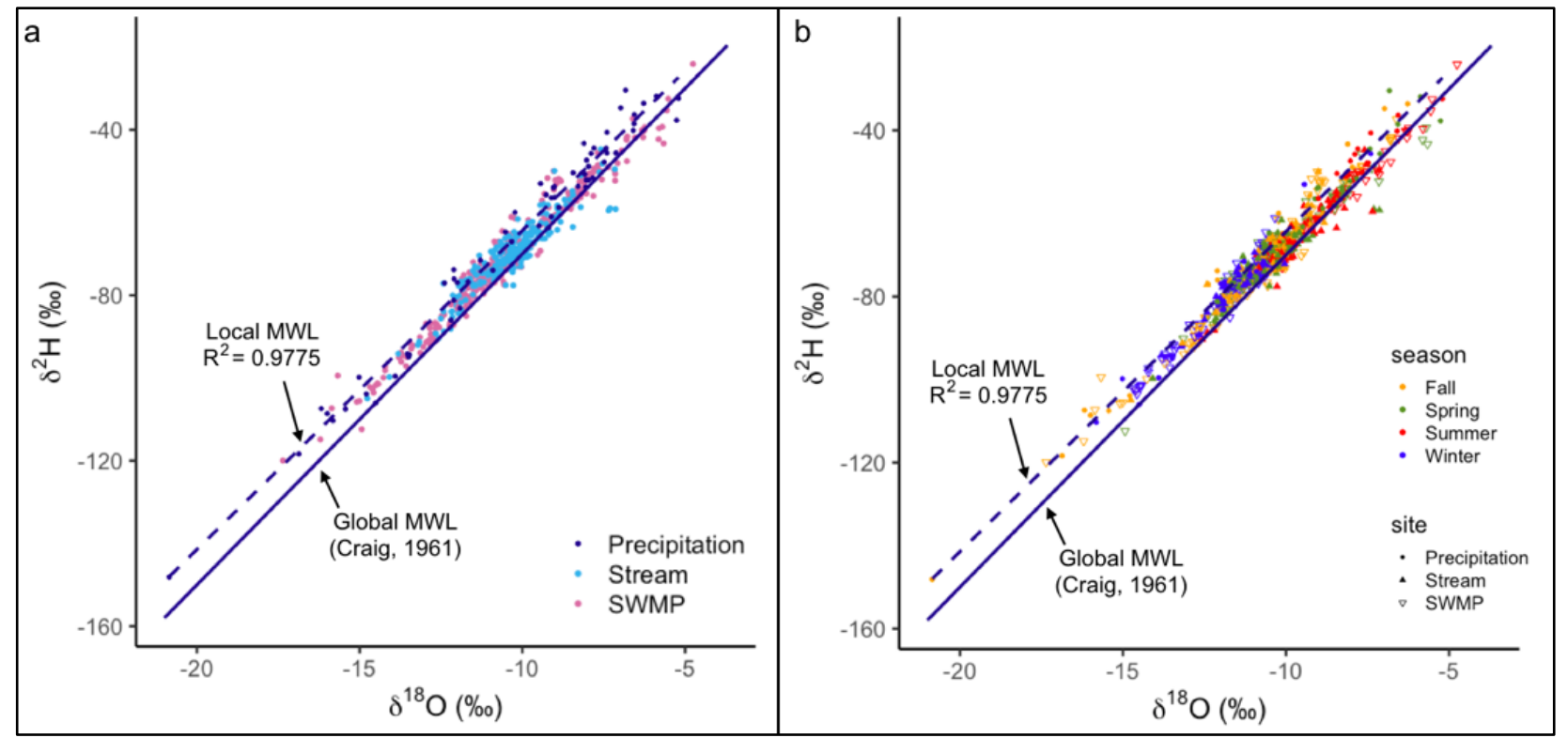

Figure 3: $\partial^{18} \mathrm{O}$ and $\partial^{2} \mathrm{H}$ sample concentrations with local (dashed line) (derived from line of best fit of precipitation samples) and global meteoric water lines (sold line) (Craig, 1961). (a) precipitation in dark blue dots, stream in light blue dots and SWMP in salmon dots. (b) precipitation as dots, stream as filled triangle and SWMP as hollow inverse triangle with fall in orange, spring in green, summer un red and winter in blue.

\subsubsection{Inverse MTT proxies}

Both MTT proxy measures illustrate that water in the forebays, aftbays and arriving at the outlets of the SWMPs is younger than the water entering the SWMPs and water arriving at all of the stream sites (Figure 4; Table 3). Stream site isotopic signatures are damper than the isotopic signatures of the SWMP sites. Similarly, the stream sites have a lower concentration of young water than the SWMP sites with 
exception to both SWMP inlet sites (Table 3). When examining the $\partial^{18} \mathrm{O}$ and $\partial^{2} \mathrm{H}$ DR and Fyw for all sites, we can see that overall, the points fall close to the 1:1 line, illustrating that either $\partial^{18} \mathrm{O}$ or $\partial^{2} \mathrm{H}$ data can be used when modelling MTT at these sites (DR_ $\partial^{18} \mathrm{O}$ vs DR_${ }^{2} \mathrm{H} \mathrm{R}^{2}=0.9875 ; \mathrm{Fyw} \_\partial^{18} \mathrm{O}$ vs Fyw_$\left.\partial^{2} \mathrm{H} \mathrm{R}^{2}=0.983\right)$.

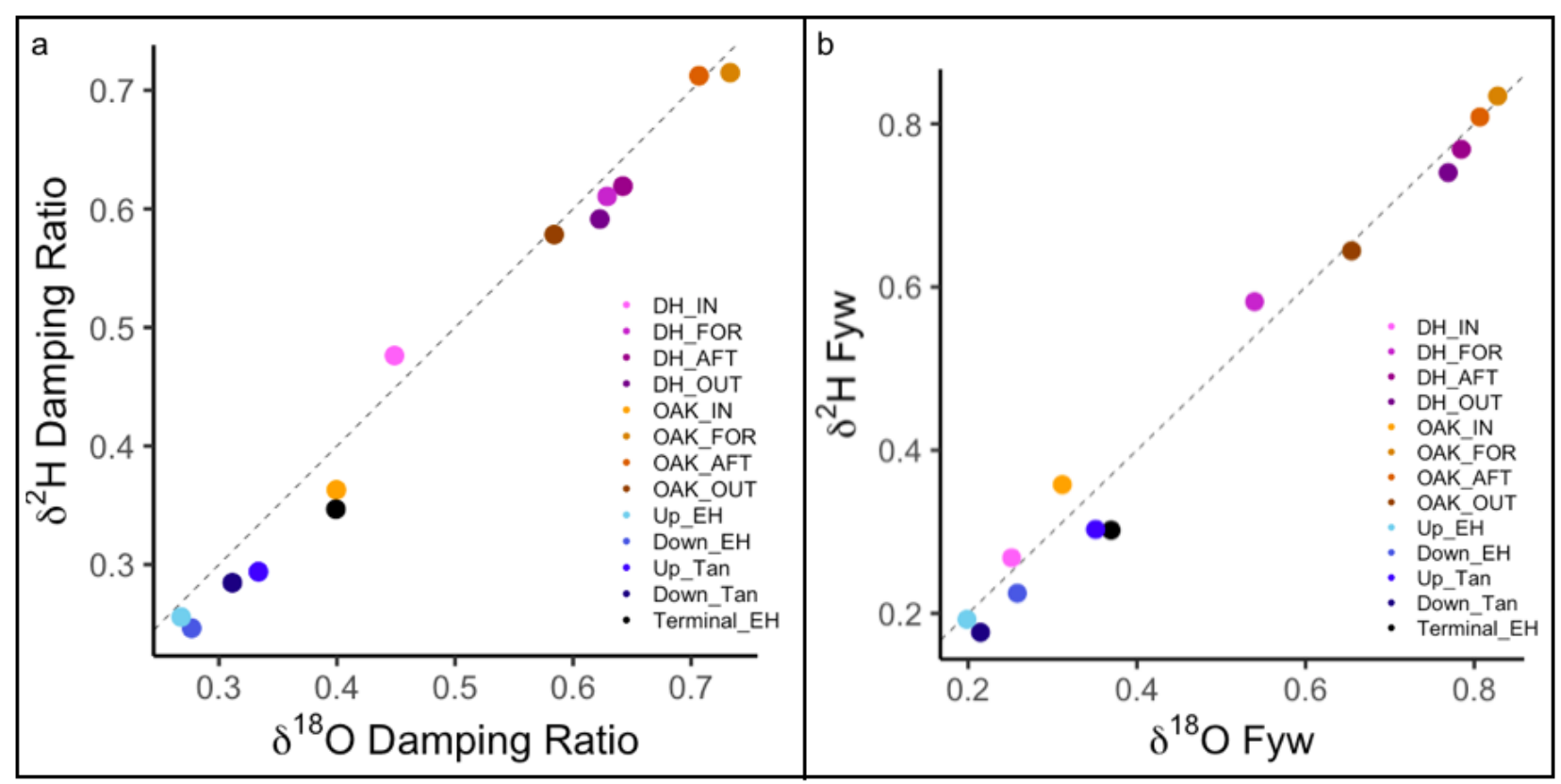

Figure 4: $\partial^{18} \mathrm{O}$ and $\partial^{2} \mathrm{H}$ mean transit time proxy measures with 1:1 line as black dashed line. (a) Damping ratio, (b) young water fraction.

Water in the forebays, aftbays and arriving at the outlets of the SWMPs is younger than the water arriving at SWMP inlets and all stream sites. These sites have DRs and Fyw above 0.5, while the stream sites and inlet DRs and Fyw are less than 0.5. The Fyw results signify that more than $50 \%$ of the water in the forebays, aftbays and outlets are younger than three months old (Figure 4; Table 3).

SWMP DH pond sites have more damp signatures and a lower Fyw than SWMP OAK counterparts. OAK's forebay and aftbay both represent the youngest water in these MTT proxy measures, while the outlet is slightly older than the two bays. In DH, 
the aftbay and outlet represent the youngest water in this SWMP with the forebay retaining older water. For both SWMPs the inlets represent the oldest water in the ponds and approach values similar to the stream samples (Table 3).

When examining the relationship between proxy measures and their catchment characteristics, highly permeable geology (sandy silt or gravel and sand) and \% DCIA, showed the strongest relationships. Catchment area showed the weakest relationship with the MTT proxy measures (Table 4; Figure 5).

Table 3: Damping ratio, young water fraction and mean transit time results.

\begin{tabular}{|c|c|c|c|c|c|c|c|c|c|c|c|}
\hline & \multirow{2}{*}{ Site } & \multicolumn{2}{|c|}{ DR } & \multicolumn{4}{|c|}{ Fyw } & \multicolumn{4}{|c|}{ MTT (Days) } \\
\hline & & $\partial^{18} \mathrm{O}$ data & $\partial^{2} \mathrm{H}$ data & $\begin{array}{l}\partial^{18} O \\
\text { data }\end{array}$ & {$[\min , \max ]$} & $\begin{array}{l}\partial^{2} H \\
\text { data }\end{array}$ & {$[\min , \max ]$} & $\begin{array}{l}\partial^{18} 0 \\
\text { data }\end{array}$ & [min, max] & $\begin{array}{c}\partial^{2} H \\
\text { data }\end{array}$ & [min, $\max ]$ \\
\hline \multirow{4}{*}{$\mathrm{DH}$} & IN & 0.45 & 0.48 & 0.25 & {$[0.21,0.30]$} & 0.27 & {$[0.23,0.31]$} & 224 & {$[164,283]$} & 209 & {$[131,287]$} \\
\hline & FOR & 0.63 & 0.61 & 0.54 & {$[0.48,0.59]$} & 0.58 & {$[0.51,0.66]$} & 91 & {$[71,110]$} & 81 & {$[70,92]$} \\
\hline & AFT & 0.64 & 0.62 & 0.78 & {$[0.72,0.85]$} & 0.77 & {$[0.69,0.84]$} & 46 & {$[40,52]$} & 48 & {$[42,55]$} \\
\hline & OUT & 0.62 & 0.59 & 0.77 & {$[0.71,0.83]$} & 0.74 & {$[0.65,0.83]$} & 48 & {$[54,46]$} & 53 & {$[46,60]$} \\
\hline \multirow{4}{*}{ OAK } & IN & 0.40 & 0.36 & 0.31 & {$[0.27,0.35]$} & 0.36 & {$[0.31,0.40]$} & 177 & {$[151,204]$} & 152 & {$[123,180]$} \\
\hline & FOR & 0.73 & 0.71 & 0.83 & {$[0.76,0.90]$} & 0.83 & {$[0.74,0.93]$} & 39 & {$[34,45]$} & 38 & {$[32,45]$} \\
\hline & AFT & 0.71 & 0.71 & 0.81 & {$[0.74,0.87]$} & 0.81 & {$[0.73,0.89]$} & 43 & {$[37,48]$} & 42 & {$[34,50]$} \\
\hline & OUT & 0.58 & 0.58 & 0.65 & {$[0.59,0.72]$} & 0.65 & {$[0.57,0.72]$} & 67 & {$[59,76]$} & 69 & {$[56,82]$} \\
\hline \multirow{5}{*}{ Stream } & Up_Tan & 0.33 & 0.29 & 0.35 & {$[0.33,0.37]$} & 0.30 & {$[0.28,0.33]$} & 155 & {$[144,166]$} & 183 & {$[164,201]$} \\
\hline & Down_Tan & 0.31 & 0.28 & 0.21 & {$[0.19,0.24]$} & 0.18 & {$[0.16,0.20]$} & 264 & {$[211,318]$} & 323 & {$[250,397]$} \\
\hline & Up_EH & 0.27 & 0.26 & 0.20 & {$[0.18,0.21]$} & 0.19 & {$[0.17,0.21]$} & 287 & {$[251,322]$} & 296 & {$[260,332]$} \\
\hline & Down_EH & 0.28 & 0.25 & 0.26 & {$[0.24,0.28]$} & 0.22 & {$[0.20,0.25]$} & 217 & {$[200,235]$} & 252 & {$[225,278]$} \\
\hline & Terminal_EH & 0.40 & 0.35 & 0.37 & {$[0.34,0.40]$} & 0.30 & {$[0.28,0.32]$} & 146 & {$[134,159]$} & 183 & {$[168,199]$} \\
\hline
\end{tabular}


Table 4: Damping ratio, young water fraction and mean transit time relationships with catchment characteristics

\begin{tabular}{|c|c|c|c|c|c|c|}
\hline \multirow{2}{*}{$\begin{array}{c}\text { Catchment } \\
\text { Characteristics }\end{array}$} & \multicolumn{2}{|c|}{ DR $\partial^{18} \mathrm{O}$} & \multicolumn{2}{c|}{ Fyw $\partial^{18} \mathrm{O}$} & \multicolumn{2}{c|}{ MTT $\partial^{18} \mathrm{O}$} \\
\cline { 2 - 7 } & $\mathrm{R}^{2}$ & Slope & $\mathrm{R}^{2}$ & Slope & $\mathrm{R}^{2}$ & Slope \\
\hline $\begin{array}{c}\text { \% Treated by SWMP } \\
\text { (topographic and DCIA) }\end{array}$ & $\mathbf{0 . 6 5}$ & $\mathbf{0 . 0 0 2 8}$ & 0.45 & 0.0034 & 0.46 & -1.4878 \\
\hline $\begin{array}{c}\text { \% sandy silt or gravel } \\
\text { and sand geology }\end{array}$ & $\mathbf{0 . 8 7}$ & $\mathbf{0 . 0 0 4 8}$ & $\mathbf{0 . 9 2}$ & $\mathbf{0 . 0 0 7 3}$ & $\mathbf{0 . 9 0}$ & $\mathbf{- 3 . 1 2 1 3}$ \\
\hline $\begin{array}{c}\text { Catchment Area }\left(\mathrm{m}^{2}\right) \\
\text { \% DCIA* }\end{array}$ & 0.04 & -0.0005 & 0.09 & -0.001 & 0.01 & 0.1717 \\
\hline $\mathbf{0 . 9 2 *}$ & $\mathbf{0 . 0 0 3 4 ^ { * }}$ & $\mathbf{0 . 9 0 ^ { * }}$ & $\mathbf{0 . 0 0 4 9 *}$ & $\mathbf{0 . 6 8 ^ { * }}$ & $\mathbf{- 1 . 8 4 1 ^ { * }}$ \\
\hline
\end{tabular}

Note: Bold $R^{2}$ and slope results indicate significant results $(p<0.05)$

${ }^{*}$ DCIA relationships do not have good spread of data (relationships are driven by SWMP outlets)

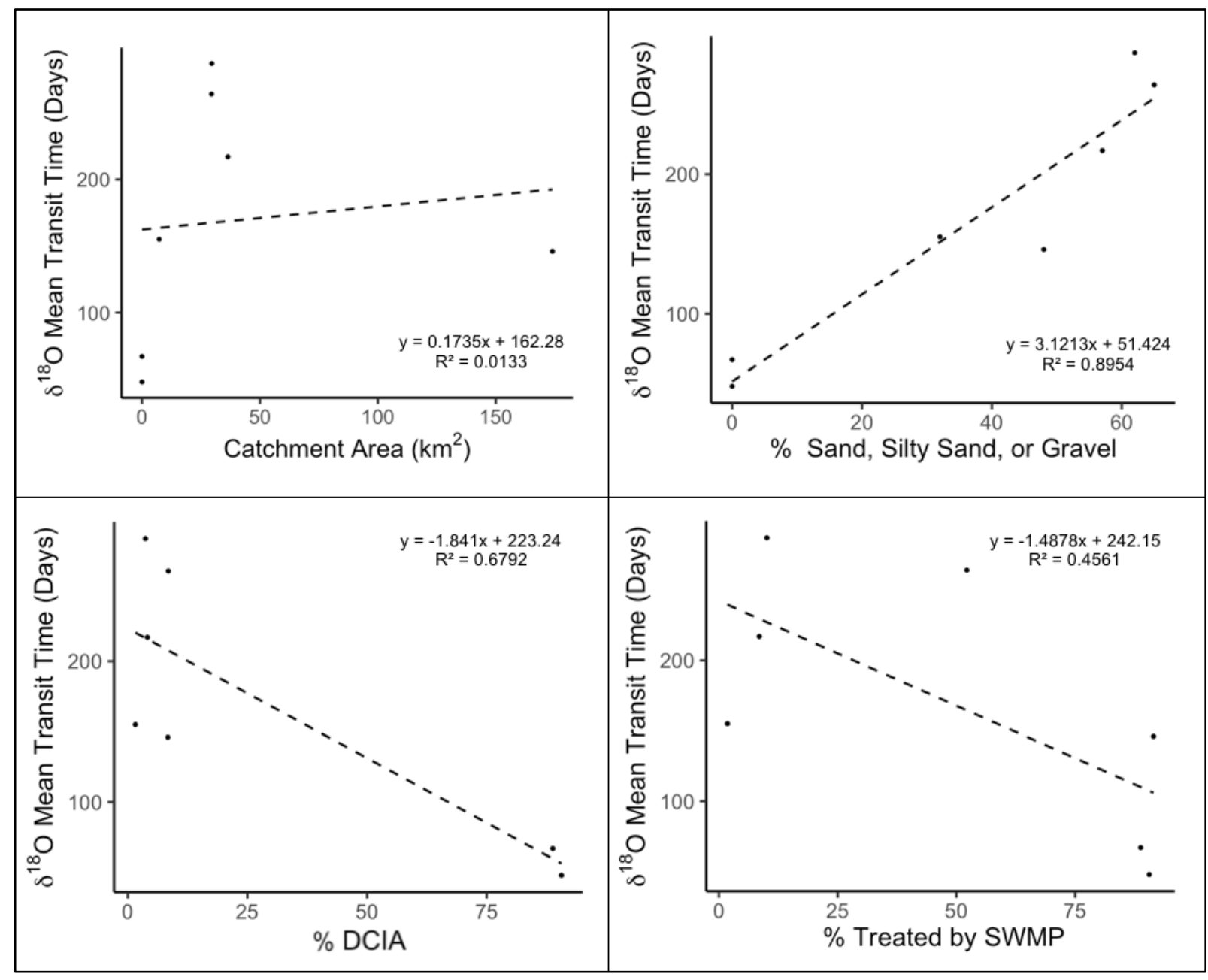

Figure 5: $\partial^{18} \mathrm{O}$ mean transit time relationships with catchment characteristics 


\subsubsection{Modelled Mean Transit Time}

The modelled MTTs of the SWMP and stream sites follow the same trend as the MTT proxy measures. MTT and DR are inversely related $\left(\partial^{18} \mathrm{O}: \mathrm{R}^{2}=0.84 ; \partial^{2} \mathrm{H}: \mathrm{R}^{2}=\right.$ 0.83). MTT and Fyw have an exponential inverse relationship $\left(\partial^{18} \mathrm{O}: \mathrm{R}^{2}=0.98 ; \partial^{2} \mathrm{H}: \mathrm{R}^{2}\right.$ $=0.98)($ Figure A1).

Water arriving at the SWMP inlets is older than the water stored in the forebays and aftbays and water arriving at the pond outlets (Figure 6a). DH is receiving older water than OAK but is releasing younger water. At $\mathrm{DH}$, the outlet is among the youngest water (48 days), along with the aftbay (46 days), followed by the forebay (91 days) and inlet (224 days). At OAK, the outlet receives the second oldest water (67 days) after the inlet (177 days), while the forebay and aftbay hold the youngest water (39 days and 43 days respectfully). As a whole, the SWMPs represent younger water than any of the stream sites (Figure 6; Table 3).

Terminal_EH and Down_Tan are the stream sites with the greatest SWMP treated area (Table 1), however their MTTs are among our "oldest" and "youngest" sampled (146 days and 264 days, respectfully). 8.4\% of Terminal_EH's $174.6 \mathrm{~km}^{2}$ catchment is treated by SWMPs through DCIA. In Down_Tan $8.5 \%$ of the $7.3 \mathrm{~km}^{2}$ catchment is treated by SWMPs through DCIA.

Up_EH (MTT of 287 days in a $29.6 \mathrm{~km}^{2}$ catchment) has older water than Down_EH (MTT of 217 days in a $36.4 \mathrm{~km}^{2}$ catchment), despite being similarly treated by SWMPs and their differences in catchment size. $3.7 \%$ and $4.1 \%$ of catchment treated by SWMPS through DCIA, in Up_EH and Down EH respectfully. Their 
counterparts, Up_Tan and Down_Tan, have the opposite relationship (Up_Tan has younger water than Down_Tan with MTTs of 155 days and 264 days, respectfully).

Water arriving at Up_EH is older than water at Up_Tan (Up_EH holds the oldest sampled water at 287 days, while Up_Tan holds among the youngest sampled stream water at 155 days). Down_EH has younger water than Down_Tan (217 days and 264 days respectfully).

Highly permeable geology (sandy silt or gravel and sand) has the best relationship with the MTT among our catchment characteristics (Figure 5). Catchment size has the weakest relationships with MTT (Table 4).

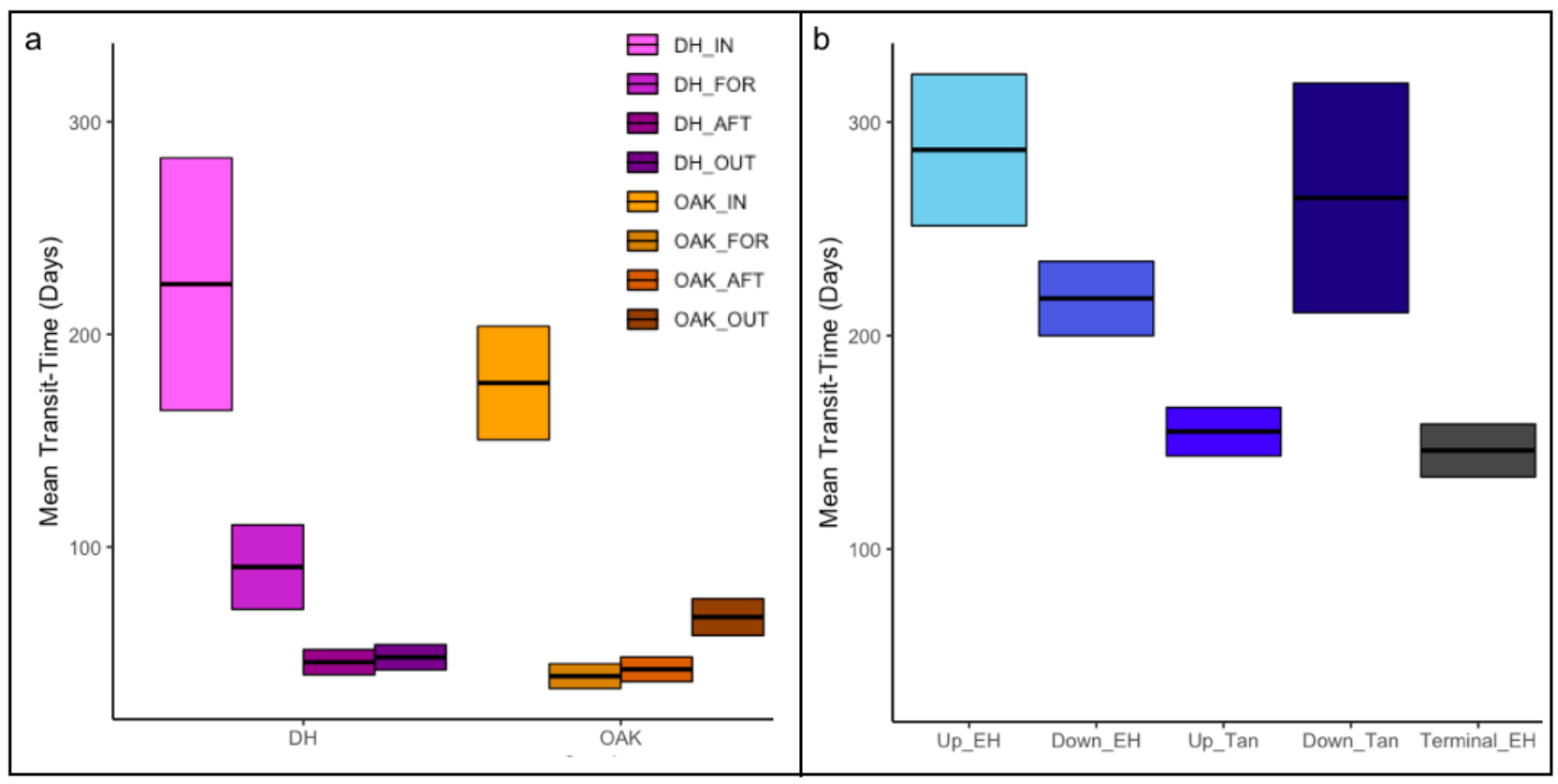

Figure 6: Mean transit times (MTT) in days of studied SWMPs (a) and stream sites (b). Line = mean MTT and box $=95 \%$ confidence intervals. 


\subsubsection{Comparing MTT, Fyw and DR Results in Urbanizing Catchments}

Relationships between the MTT, DR and Fyw results were evaluated. Fyw and DR displayed positive relationships when compared with each other for both $\partial^{2} \mathrm{H}$ and $\partial^{18} \mathrm{O}$ data. As expected Fyw and DR were inversely related to MTT. Fyw and MTT results have the best relationship with each other for both $\partial^{2} \mathrm{H}$ and $\partial^{18} \mathrm{O}$ data (Figure 7). In these catchments Fyw has the best relationships with both DR and MTT. DR has the weakest relationships with other water age metrics (Figure 7). When ranking the water age from oldest to youngest, MTT and Fyw had the same ranking order when comparing ranks with each other for both $\partial^{2} \mathrm{H}$ and $\partial^{18} \mathrm{O}$ results. DR ranks were similar to Fyw and MTT but varied between some sites, resulting in a weaker relationship (Figure 8). Between all water age matric ranks of $\partial^{18} \mathrm{O}$ data, Up_EH and Oak_FOR represented the oldest and youngest water, respectfully. When observing the water age metric ranks for $\partial^{2} \mathrm{H}$ data, all metrics classified Oak_FOR as the youngest water, however DR deviated from Fyw and MTT by ranking Down_EH as having the oldest water, while Fyw and MTT classified Down_Tan as the oldest. 


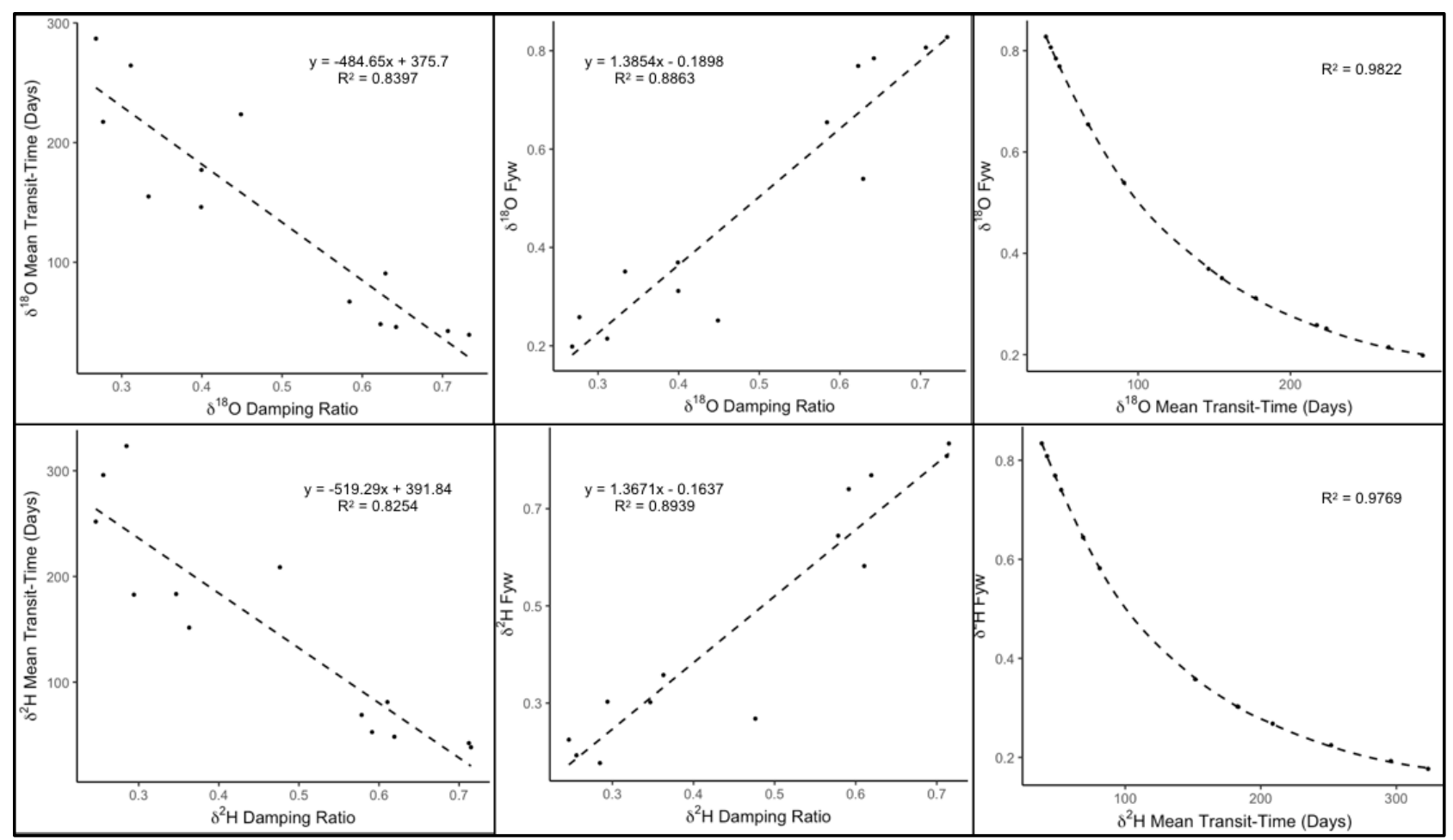

Figure 7: Comparison of Water age metrics. Fyw, MTT and DR based on $\partial^{2} \mathrm{H}$ and $\partial^{18} \mathrm{O}$ data. Points in black, line of best fit in black dashed line.

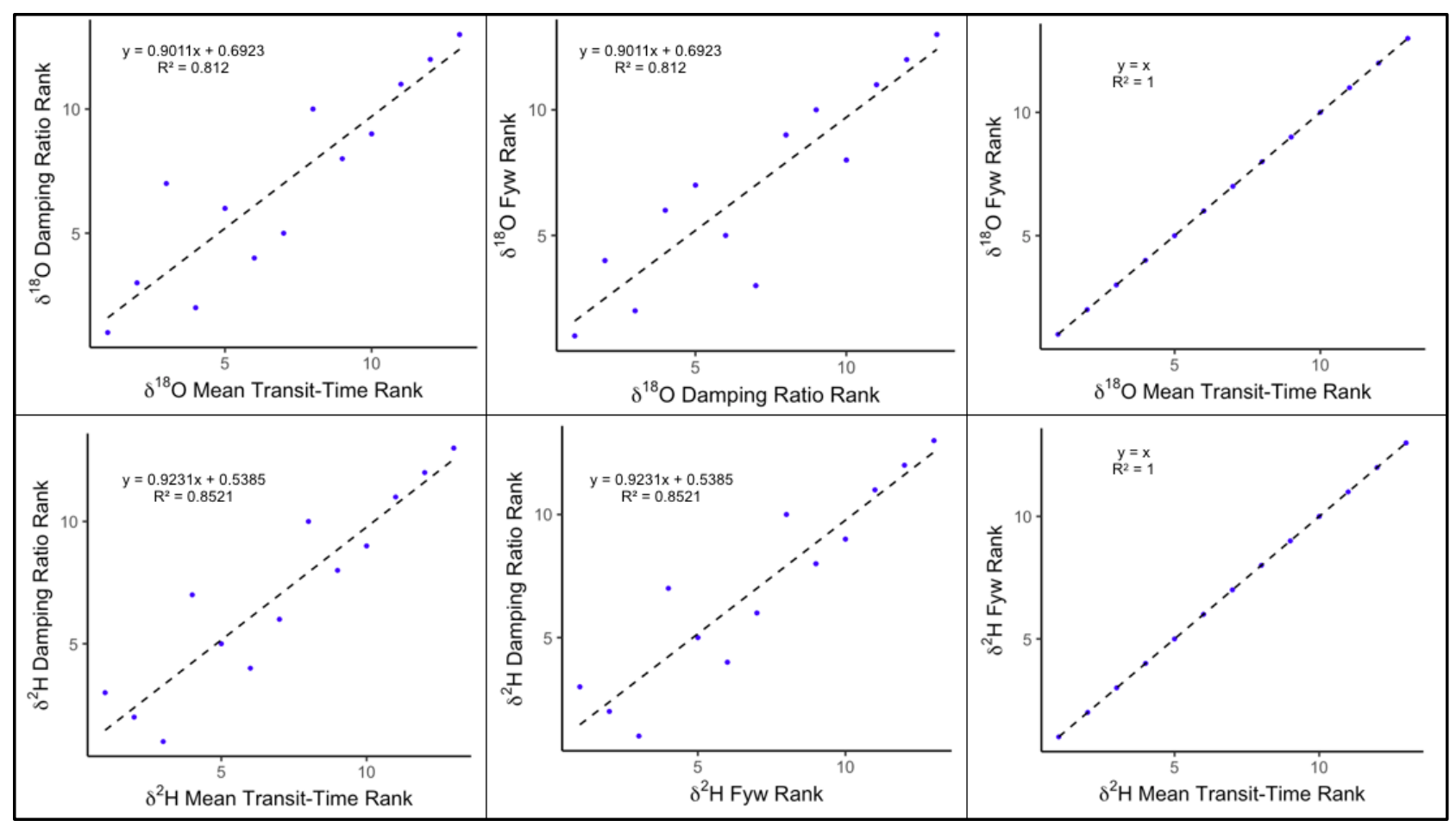

Figure 8: Comparison of Water age metric ranks. Fyw, MTT and DR based on $\partial^{2} \mathrm{H}$ and $\partial^{18} \mathrm{O}$ data. Points in blue, line of best fit in black dashed line. 1 = oldest water, 13 = youngest water. 


\subsection{Discussion}

\subsubsection{How does the MTT of water entering, within and exiting SWMPs compare?}

We examined the MTTs at different locations in the SWMPs (inlet, forebay, aftbay and outlet) and found that water entering the inlets of the SWMPs is consistently older than the water in or exiting the SWMP. This may be due to (i) significant shallow groundwater infiltrating into broken sewers and/or thermal and densitometric stratification of the ponds . Regular field observations of the inlet pipes of both ponds verified that low flow occurs near continuously in between precipitation and snowmelt events. This low flow has a relatively low specific conductivity (W. Lam, pers. comm.) and is most likely dominated by groundwater. This suggests that groundwater is able to infiltrate into breaks in the storm sewer pipes somewhere in the pipe network connected to each pond. Given that only $25 \%$ of our samples were taken during event flow, our inlet sampling is likely biased toward baseflow flow conditions, causing an overestimation of our inlet MTTs. A future study incorporating event sampling more substantively is recommended to better represent the full distribution of water ages entering these SWMPs. SWMPs also experience a lack of mixing due to their small surface areas which can hinder the wind mixing that occurs in larger waterbodies (Mazumder \& Taylor 1994; Xenopoulos \& Schindler, 2001; McEnroe et al., 2013).Stratification in the SWMP bays, and the fact that we sampled from the surface of the ponds, may also be biasing our estimation of the MTT of water in the ponds. During warm periods, groundwater entering the ponds would be is colder than the warmer surface runoff, which could result in the older groundwater sinking to the bottom of the pond and the younger event water to sit at the surface, potentially contributing to the 
underestimation of MTTs. During the cold season, road salt laden meltwater entering the ponds can also lead to stratification (i.e., densimetric; McEnroe et al., 2013). In this case, the water sampled at the surface would more likely be the fresher groundwater inputs, potentially causing an overestimation of MTTs. Measuring isotope concentrations at varying depths in the SWMPs, over different seasons, is recommended for future research. Overall, our understanding of inter-SWMP variability in MTT would benefit from a larger sample size so that the influence of the condition of the connected sewer network, the design of the SWMP (e.g., bottom draw vs channel drained), and pond stratification dynamics on MTT can be examined more robustly.

\subsubsection{Do differences in land cover and/or SWMP treatment influence catchment-scale} water age?

Water age at the upstream and downstream of stream reaches were observed for two catchments with different levels of SWMP treatment (Up_Tan: 1.6\%; Down_Tan: 8.5\%; Up_EH: 3.7\%; Down_EH: $4.1 \%$ ), along with the outlets at two SWMPs. The MTT results from these 7 sites were grouped and examined against various catchment characteristics. It was found that catchments with more permeable surficial geology (sandy silt, gravel and sand geology), indicative of higher groundwater-surface water interactions, had higher MTTs. The relationship between more permeable surficial geology and calculated water age metrics represented the strongest $R^{2}$ relationship of all catchment characteristics suggest that in urbanizing catchments, surficial geology still plays an important role in determining water age (Figure 8; Table 4). Catchment size has been found to have little influence on MTT in non-urban catchments (Hrachowitz, Soulsby, Tetzlaff, \& Speed, 2010) and we found a similar result in this 
study as catchment size was found to have the weakest relationship with MTT of the studied catchment characteristics. Water age decreased in catchments with higher $\%$ area treated by SWMPs. Suggesting that although SWMPs are designed to mitigate flashy hydrographs and slow water from flushing from urban catchments, in urban areas treated by SWMPs, water is exiting the catchments faster as urban area and SWMP treatment increases. It is important to note that the range of catchment characteristics across our sites is broad but, in some cases, (e.g., DCIA), 2-3 high values are providing a lot of leverage in the relationship. Additionally, given that $25 \%$ of our samples were taken during event flow and $75 \%$ were taken during baseflow, our findings are biased towards baseflow conditions. Future studies which include additional study sites of varying catchment characteristics are needed to verify these relationships and examine the combined influence of catchment characteristics and stormwater treatment.

\subsubsection{Do MTT, DR and Fyw have comparable results in urbanizing watersheds?}

MTT, DR and Fyw results are comparable in these urbanizing catchments. Fyw had the best relationship with MTT when compared to the DR's relationship with MTT. This was also true for ranking of oldest to youngest water, Fyw and MTT shared the same ranking order for all sites. Although all three water age metrics produced the same youngest and oldest water sites for and $\partial^{18} \mathrm{O}$ data results, DR produced a similar, but not exact ranking to MTT and Fyw. This agrees with non-urban studies that found that all three water age metrics produce the comparable results and water age ranks (e.g., Kirchner, 2016b; Bansah \& Ali, 2018). These results demonstrate that while DR is a useful tool to perform a quick estimation of MTT, Fyw estimations better align with MTT estimations when using either $\partial^{2} \mathrm{H}$ or $\partial^{18} \mathrm{O}$ data in urbanizing catchments. 


\subsection{Conclusion}

MTTs at the catchment and SWMP scale were examined to explore the influence that SWMP treatments have on water age in urban streams and dynamics within SWMPs. The MTTs of water entering, within and leaving two SWMPs were determined, along with two stream reaches representing different SWMP treated area and the watershed of which they belong. The water age metrics of MTT by sine-wave fitting, Fyw and DR were calculated using $\partial^{18} \mathrm{O}$ and $\partial^{2} \mathrm{H}$ data. We found that the SWMPs' oldest water was found at the inlets (177 days and 224 days), and water within and exiting the SWMPs is younger (ranging from 39 days to 91 days). This discrepancy suggests significant groundwater infiltrating into broken sewers and flowing into the ponds. Future investigations into the isotope mass balance of SWMPs will aid in understanding the movement of the "older" water in SWMPs. Surficial geology was found to have the greatest influence on the catchments' MTT. Fyw produced estimates that better aligned with MTT calculations, while DR, although a useful quick MTT estimation, has weaker correlations with calculated MTT results. Additional research of MTTs in different storm water control measures (i.e. low impact development, bioswales, wet SWMPs, dry SWMPs) and catchments with varying stormwater treated area would improve our understanding of how urban catchments store and release water. More research is needed on water storage and release from urban catchments to better understand SWMP function, contaminant fate and transport in urban areas to natural waterways. 


\section{Summary}

Expansion of impervious surface in urbanizing areas result in elevated flood risk, degraded water quality and 'flashy' hydrologic response in urban waterways when compared to their natural counterparts. These responses to urbanization are mitigated by stormwater control measures, like stormwater management ponds (SWMPs). SWMPs are engineered into the stream network with the intent to return flow rates to the treated area's predevelopment flow rates. Given the prevalence of the use of SWMPs as a stormwater management control measure, there is little known about how SWMPs affect hydrological transit time (water age) at the catchment scale which is needed to better understand water storage and release dynamics in these systems.

The aim of this study was to examine water age in SWMPs and the influence that varying SWMP control along with other catchment characteristics have on water age in urban streams. Damping ratio (DR), young water fraction (Fyw) and mean transit time by sine-wave fitting (MTT) were calculated within two SWMPs (inlet, forebay, aftbay and outlet), at the upstream and downstream sites of two stream reaches and at the studied watershed's outlet. We found that the water entering the SWMPs was constantly older than water in or exiting these systems. Suggesting that groundwater is entering the SWMPs at the inlet. This was also supported by our analysis of MTT results with surficial geology. We found that surficial geology had the best relationship with MTT (MTT increased in catchments as \% more permeable surficial geology increased). Indicating that surficial geology has a large influence on MTT of the catchment characteristics examined in this study. Fyw produced water age estimates that better aligned with the MTT, while DR, although a useful quick MTT estimation, had weaker 
correlations with estimated MTT results. Future study is required to test for cumulative effects catchment characteristics on water age in catchments of varying stormwater management treated area to better inform stormwater mitigation strategies, and pollutant fate in urban areas. 


\section{Appendix 1}

Table A1: $R^{2}$ of fitted sine-waves for $\partial^{18} \mathrm{O}$ and $\partial^{2} \mathrm{H}$ data.

\begin{tabular}{|c|c|c|c|}
\hline \multirow{2}{*}{\multicolumn{2}{|c|}{ Site }} & \multicolumn{2}{|c|}{$R^{2}$} \\
\hline & & $\partial^{18} 0$ data & $\partial^{2} \mathrm{H}$ data \\
\hline \multirow{4}{*}{ DH } & IN & 0.143 & 0.124 \\
\hline & FOR & 0.351 & 0.373 \\
\hline & AFT & 0.741 & 0.660 \\
\hline & OUT & 0.768 & 0.679 \\
\hline \multirow{4}{*}{ OAK } & IN & 0.238 & 0.310 \\
\hline & FOR & 0.564 & 0.521 \\
\hline & AFT & 0.592 & 0.505 \\
\hline & OUT & 0.768 & 0.679 \\
\hline \multirow{5}{*}{ Stream } & Up_Tan & 0.546 & 0.456 \\
\hline & Down_Tan & 0.223 & 0.157 \\
\hline & Up_EH & 0.279 & 0.247 \\
\hline & Down_EH & 0.421 & 0.341 \\
\hline & Terminal_EH & 0.671 & 0.630 \\
\hline \multicolumn{2}{|c|}{ Precipitation } & 0.477 & 0.419 \\
\hline
\end{tabular}




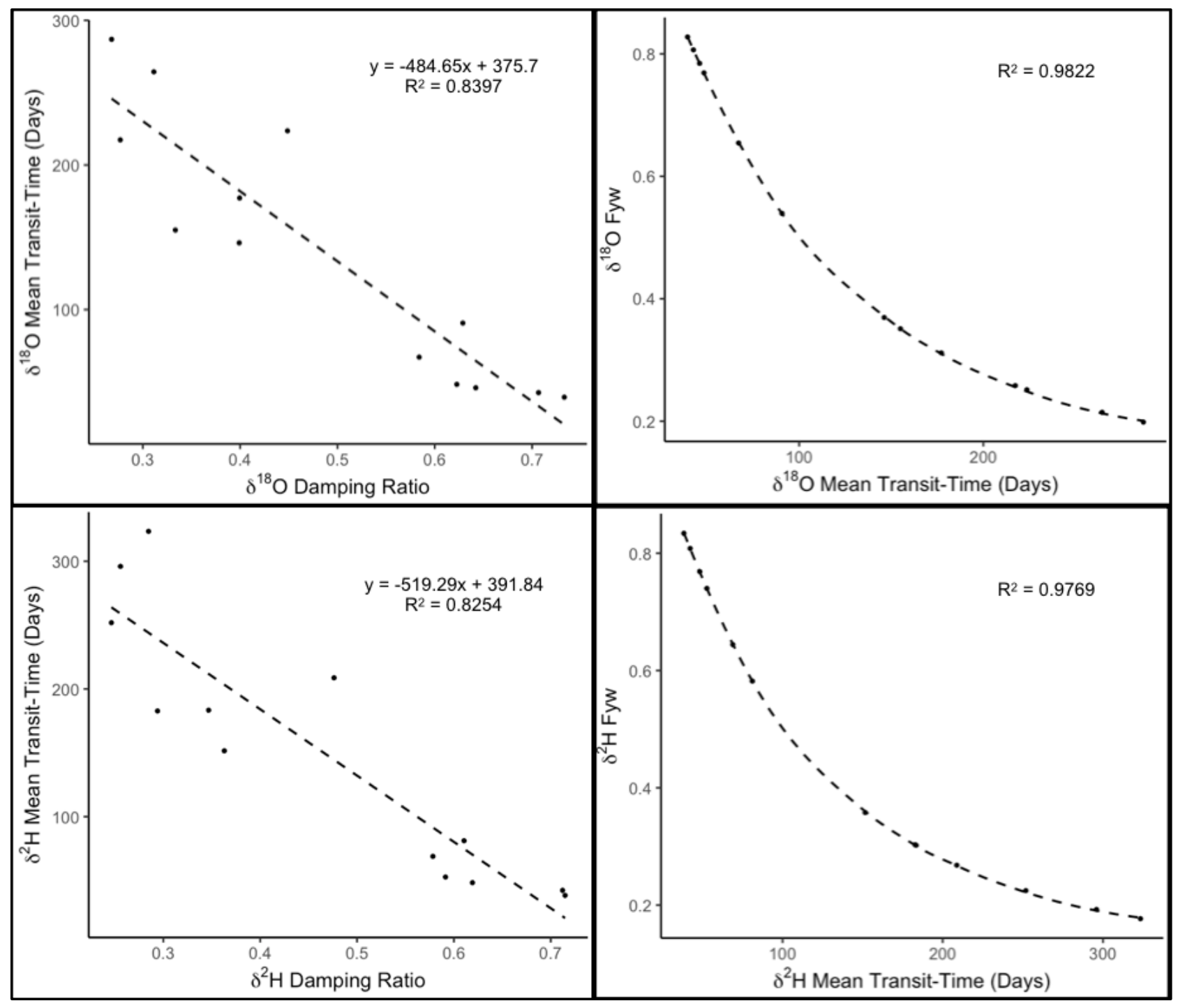

Figure A1: MTT result comparisons to MTT proxy measure results. 


\section{References}

Aggarwa, P. K., Gat, J., \& Froehlich, K. F. (2007). Isotopes in the water cycle: Past, present and future of a developing science. Dordrecht: Springer.

Ala-aho, P., Tetzlaff, D., McNamara, J., Laudon, H., Kormos, P., \& Soulsby, C. (2017). Modeling the isotopic evolution of snowpack and snowmelt: Testing a spatially distributed parsimonious approach. Water Resources Research, 53(7), 4813 5830.

Anderson, B., Watt, W., \& Marsalek, J. (2002). Critical issues for stormwater ponds: learning from a decade of research. Diffuse/Non-point Pollut. Watersheds Manage, 45, 277 - 283.

Anderson, T., Bestland, E., Soloninka, L., Wallis, I., Banks, E., \& Pichler, M. (2017). A groundwater salinity hotspot and its connection to an intermittent stream identified by environmental tracers (Mt Lofty Ranges, South Australia). Hydrogeology, 25, 2435 - 2451.

Arango, C. P., Balz, A. D., Beaulieu, J. J., Fritz, K. M., Hill, B. H., Elonen, C. M., \& Kaushal, S. S. 2017. Urban infrastructure influences dissolved organic matter quality and bacterial metabolism in an urban stream network. Freshwater Biology, 62, 1917-1928.

Arnold, C., \& Gibbons, C. (1996). Impervious surface coverage: The emergence of a key environmental indicator. Journal of the American Planning Association, 62(2), $243-258$.

Bachoc, A., Tabuchi, J., Chebbo, G., Philippe, J. (1994). Urban stormwater pollution: Quantity, origin and nature. La Houille Blanche, 1(2), 21 - 33. 
Bansah, S., \& Ali, G. (2018). Streamwater ages in nested, seasonally cold Canadian watersheds. Hydrological Processes, 33(4), 495 - 511.

Barbosa, A., Fenandes, J., \& David, L. (2012). Key issues for sustainable urban stormwater management. Water Research, 46, 6787 - 6798.

Berndtsson, J. (2010). Green roof performance towards management of runoff water quantity and quality: A review. Ecological Engineering, 36, 351 - 360.

Betts, A., Gharabaghi, B., \& McBean, E. (2014). Salt vulnerability assessment methodology for urban streams. Journal of Hydrology, 517, 877 - 888.

Booth, D., \& Bledsoe, B. (2009). Streams and Urbanization, the Water Environment of Cities. Springer, USA, pp. 93 - 123.

Buttle, J. (1994). Isotope hydrograph separations and rapid delivery of pre-event water from drainage basins. Progress in Physical Geography, 18(1), 16 - 41.

Burns, D. (2002). Stormflow-hydrograph separation based on isotopes: The thrill is gone? What's next? Hydrological Processes. 16(7): 1515 - 1517.

Burns, D., \& McDonnell, J. (1998). Effects of a beaver pond on runoff processes comparison of two headwater catchments. Journal of Hydrology, 205, 248 264.

Cassie, D., Pollock, L., Cunjak, A. (1996). Variation in stream water chemistry and hydrograph separation in a small drainage basin. Journal of Hydrology, 178(14), $137-157$.

Chang, N., Lu, J., Chui, T., \& Hartshorn, N. (2018). Global policy analysis of low impact development for stormwater management in urban regions. Land Use Policy, 70, 368-383. 
Craig, H., (1961). Isotopic variations in meteoric waters. Science, 133, 1702 - 1703.

Drake, J., \& Guo, Y. (2008). Maintenance of Wet Stormwater Ponds in Ontario.

Canadian Water Resources Journal, 33(4), 351 - 368.

Dunne, T. \& Leopold, L. (1998). Water in environmental planning. New York: Freeman.

Eckart, K., McPhee, Z., \& Bolisetti, T. (2017). Performance and implementation of low impact development - A review. Science of the Total Environment, 607 - 608, $413-432$.

Ellis, J., \& Marsalek, J. (1996). Overview of urban drainage: Environmental impacts and concerns, means of mitigation and implementation policies. Journal of Hydraulic Research, 34(6), 723 - 732.

Ferrara, R., \& Hildick-Smith, A. (1982). A modelling approach for storm water quantity and quality control via detention basins. American Water Resource Association, 18(6), 975 - 981.

Frederickson, G., \& Criss, R. (1999): Isotope hydrology and residence times of the unimpounded Meramec River Basin, Missouri: Chemical Geology, 157, 303 317.

Fry, T., \& Maxwell, R. (2017). Evaluation of distributed BMPs in an urban watershed-High resolution modeling for stormwater management. Hydrological Processes, 31(15), 2700 - 2712.

Garvelmann, J., Warscher, M., Leonhardt, G., Franz, H., Lotz, A., \& Kunstmann, H. (2017). Quantification and characterization of the dynamics of spring and stream water systems in the Berchtesgaden Alps with a long-term stable isotope dataset. Journal of Environmental Earth Sciences, 72(22). 
Gat, J., \& Levy, Y. (1978). Isotope hydrology of inland sabkhas in the Bardawil area, Sinai. Limnol. Journal of Oceanography, 23, $841-850$.

Gibson, J., Birks, S., \& Yi, Y. (2016). Stable isotope mass balance of lakes: a contemporary perspective. Quaternary Science Reviews, 131, 316 - 328.

Gonfiantini, R., (1986). Environmental isotopes in lake studies. In: Fritz, P., Fontes, J.Ch (Eds.), Handbook of Environmental Isotope Geochemistry, vol. 3. Elsevier, New York, pp. $113-168$.

Grimm, N., Faeth, S., Golubiewski, N., Redman, C., Wu, J., Bai, X., \& Briggs, J. (2008). Global change and the ecology of cities. Science, 319(5864), 756 - 760.

Haq, R., \& James, W. (2002). Thermal enrichment of stream temperature by urban storm waters. Advances in Modeling the Management of Stormwater Impacts. CHI, Guelph, Canada 5, $139-157$.

Hooper, R. \& Shoemaker, C. (1986). A comparison of chemical and isotopic hydrograph separation. Water Resources Research, 22(10), 1444 - 1454.

Horita, J., (1990). Stable isotope paleoclimatology of brine inclusions in halite: modelling and application to Searles Lake, California. Geochimica et Cosmochimica Acta, $54,2059-2073$.

Houhou, J., Lartiges, B., France-Lanord, C., Guilmette, C., Poix, S., \& Mustin, C. (2010). Isotopic tracing of clear water sources in an urban sewer: A com- bined water and dissolved sulfate stable isotope approach. Water Research, 44(1), 256 266.

Hrachowitz, M., Benettin, P., Breukelen, B., Fovet, O., Howden, N., Ruiz, L., \& Wade, A. (2016). Transit times-the link between hydrology and water quality at the 
catchment scale. Wiley Interdisciplinary Reviews: Water, 3(5), 629 - 657.

Hrachowitz, M., Fovet, O., Ruiz, L., \& Savenije, H. (2015). Transit time distributions, legacy contamination and variability in biogeochemical 1/fa scaling: how are hydrological response dynamics linked to water quality at the catchment scale? Hydrological Processes, 29, 5241 - 5256.

Hrachowitz, M., Soulsby, C., Tetzlaff, D., \& Speed, M. (2010). Catchment transit times and landscape controls—does scale matter? Hydrological Processes, 24, 117 125.

Huang, J., Tu, Z., Du, P., Lin, J., \& Li, Q. (2010). Uncertainties in stormwater runoff data collection from a small urban catchment, Southeast China. Journal of Environmental Sciences, 22(11), 1703 - 1709.

Huth, A., Leydecker, A., \& Sickmanet, J. (2004). A two-component hydrograph separation for three high-elevation catchments in the Sierra Nevada, California. Hydrological Processes, 18(9), 1721 - 1733.

libery, B., Foster, I., \& Donoghue, P. (1982). Precipitation and water quality: a geographical perspective. Processes in Physical Geography, 6(4), 524 - 540.

Iqbal, M. (1998). Application of environmental isotopes in storm-discharge analysis of two contrasting stream channels in a watershed. Water Research, 32(10), 2959 $-2968$.

James, W., \& Verspagen, B., (1996). Thermal enrichment of stormwater by urban pavement. Journal of Water Management Modeling, 195 - 08.

Jankowfsky, S., Branger, F., Braud, I., Gironás, J., \& Rodriguez, F. (2013). Comparison of catchment and network delineation approaches in com- plex suburban 
environments: Application to the Chaudanne catchment, France. Hydrological Processes, 27(25), 3747 - 3761.

Jefferson, A., Bell, C., Clinton, S., \& Mcmillan, S. (2015). Application of isotope hydrograph separation to understand contributions of stormwater control measures to urban headwater streams. Hydrological Processes, 29(25), $5290-5306$.

Jefferson, A., Bhaskar, A., Hopkins, K., Fanelli, R., Avellaneda, P., \& McMillan, S. (2017). Stormwater management network effectiveness and implications for urban watershed function: A critical review. Hydrological Processes, 31, 4056 4080.

Kanduč, T., Mori, N., Kocman, D., Stibilj, V., \& Grassa, F. (2012). Hydrogeochemistry of Alpine springs from North Slovenia: Insights from stable isotopes. Chemical Geology, 300(301), $40-54$.

Kaushal, S., \& Belt, T. (2012). The urban watershed continuum: Evolving spatial and temporal dimensions. Urban Ecosystems, 15(2), 409 - 435.

Kaushal, S., Mcdowell, W., Wollheim, W., Johnson, T., Mayer, P., Belt, K., \& Pennino, M. (2015). Urban evolution: The role of water. Water, 7(8), 4063 - 4087.

Kayembe, A., \& Mitchell, C. (2018). Determination of subcatchment and watershed boundaries in a com- plex and highly urbanized landscape. Hydrological Processes, 32, 2845 - 2855.

Kirchner, J. (2016a). Aggregation in environmental systems - Part 1: Seasonal tracer cycles quantify young water fractions, but not mean transit times, in spatially heterogeneous catchments. Hydrology and Earth System Sciences, 20, 279 - 
297.

Kirchner, J. (2016b). Aggregation in environmental systems - Part 2: Catchment mean transit times and young water fractions under hydrologic nonstationarity. Hydrology and Earth System Sciences, 20, 299 - 328.

Klaus, J., \& McDonnell, J. (2013). Hydrograph separation using stable isotopes: Review and evaluation. Journal of Hydrology, 505, 47 - 64.

Klemetson, S., \& Rogers, G. (1985). Aquaculture pond temperature modeling. Aquacultural Engineering, 4, 191 - 208.

Li, X., Sugimoto, A., \& Ueta, A. (2017). Spatial and temporal variations of stable isotopes in precipitation in midlatitude coastal regions. Hydrological Processes, 31(17), 3029 - 3044

Lichtblau, E., \& Oswald C.J. (2019). Classification of impervious land-use features using object-based image analysis and data fusion. Computers, Environment and Urban Systems, 75, $103-116$.

Liu, Y., Engel, B. A., Collingsworth, P. D., and Pijanowski, B. C. (2017). Optimal implementation of green infrastructure practices to minimize influences of land use change and climate change on hydrology and water quality: Case study in Spy Run Creek watershed, Indiana. Science of the Total Environment, 601-602, $1400-1411$.

Machavaram, M., Whittemore, D., \& Conradet, M. (2006). Precipitation induced stream flow: An event based chemical and isotopic study of a small stream in the Great Plains region of the USA. Journal of Hydrology, 330(3-4), $470-480$.

Mazumder, A., \& Taylor, W. (1994) Thermal structure of lakes varying in size and water 
clarity. Limnology and Oceanography, 39, 968 - 976.

McEnroe, N., Buttle, J., Marsalek, J., Pick, F., Xenopoulos, M., \& Frost, P. (2013).

Thermal and chemical stratification of urban ponds: Are they 'completely mixed reactors'? Urban Ecosyst, 16, 327 - 339.

McGuire, K., DeWalle, D., \& Gburek, W. (2002). Evaluation of mean residence time in subsurface waters using oxygen-18 fluctuations during drought conditions in the mid- Appalachians. Journal of Hydrology, 261, 132 - 149.

McGuire, K., \& McDonnell, J. (2006). A review and evaluation of catchment transit time modeling. Journal of Hydrology, 330, 543 - 563.

McGuire, K. J., \& McDonnell, J. J. (2015). Tracer advances in catchment hydrology. Hydrological Processes, 29, 5135-5138.

McGuire, K., Weiler, M., \& McDonnell, J. (2007). Integrating tracer experiments with modeling to assess runoff processes and water transit times. Advances in Water Resources, 30, 824 - 837.

Metsaranta, N., Kotola, J., \& Nurminen, J. (2005). Effects of urbanization on runoff water quantity and quality: Experiences from test catchments in Southern Finland. International Journal of River Basin Management, 3(3), 229-234.

Ontario Ministry of Natural Resources and Forestry. (2017). Ontario integrated hydrology data.

Ontario Ministry of Natural Resources and Forestry - Provincial Mapping Unit. (2013). 2013 Orthoimagery Project.

Ontario Ministry of Northern Development and Mines. (1988). Quaternary Geology of Ontario. 
Ontario Ministry of the Environment (2003). Stormwater management practices planning and design manual. Retrieved from: https://www.ontario.ca/document/ stormwater-management-planning-and-design manual/environmental-planning Ontario Ministry of the Environment (2018). Watershed planning in Ontario: Guidance for land-use planning authorities. Retrieved from: http://www.downloads.ene.gov.on.ca/envision/env_reg/er/documents/2018/0131817_DraftGuidance.pdf

Parajulee, A., Wania, F., \& Mitchell, C. (2019). Hydrological transit times in nested urban and agricultural watersheds in the Greater Toronto Area, Canada. Hydrological Processes, 33, 350 - 360.

R Core Team (2017). R: A language and environment for statistical computing. R Foundation for Statistical Computing, Vienna, Austria. URL http://www.Rproject.org/

Saraswat, C., Kumar, P., \& Mishra, B. (2016). Assessment of stormwater runoff management practices and governance under climate change and urbanization: An analysis of Bangkok, Hanoi and Tokyo. Environmental Science and Policy, $64,101-117$.

Schmitt, T., Thomas, M., \& Ettrich, N. (2004). Analysis and modeling of flooding in urban drainage systems. Journal of Hydrology, 299(3), 300 - 311.

Schulte-Hostedde, B., Walters, D., Powell, C., \& Shrubsole, D. (2007). Wetland management: An analysis of past practice and recent policy changes in Ontario. Journal of Environmental Management, 82(1), 83-94.

Sidle, W., \& Lee, P. (1999). Urban stormwater tracing with the naturally occurring 
deuterium isotope. Water Environment Research, 71(6), 1251-1256.

Smith, K. (1979). Trends in water resource management. Progress in Physical Geography, 3(2), 236-254.

Sonnenwald, F., Guymer, I., \& Stovin, V. (2018). Computational fluid dynamics modelling of residence times in vegetated stormwater ponds. Proceedings of the Institution of Civil Engineers - Water Management, 171(2), 76 - 86.

Soulsby, C., Birkel, C., Geris, J., \& Tetzlaff, D. (2015). Spatial aggregation of timevariant stream water ages in urbanizing catchments. Hydrological Processes. 29(13), $3038-3050$.

Soulsby, C., Birkel, C., \& Tetzlaff, D. (2014). Assessing urbanization impacts on catchment transit times. Geophysical Research Letters, 41(2), 442-448.

Soulsby, C., Piegat, K., Seibert, J. \& Tetzlaff, D. (2011). Catchment-scale estimates of flow path partitioning and water storage based on transit time and runoff modelling. Hydrological Processes, 25, 3960 - 3976.

Tetzlaff, D., Buttle, J., Carey, S. K., McGuire, K., Laudon, H., \& Soulsby, C. (2015). Tracer-based assessment of flow paths, storage and runoff generation in northern catchments: A review. Hydrological Processes, 29, 3475-3490.

Tetzlaff, D., Malcolm, I., \& Soulsby, C. (2007). Influence of forestry, environmental change and climatic variability on the hydrology, hydrochemistry and residence times of upland catchments. Journal of Hydrology, 346, 93 - 111.

Tetzlaff, D., Seibert, J., McGuire, K., Laudon, H., Burns, D., Dunn, S., \& Soulsby, C. (2009). How does landscape structure influence catchment transit time across different geomorphic provinces? Hydrological Processes, 23(6), 945 - 953.

Tekeli, A., Sorman, A., Sensoy, A., \& Şorman, Ü. (2003). Design, installation of a 
snowmelt lysimeter and analysis for energy mass balance model studies in Turkey. 60th EASTERN SNOW CONFERENCE Sherbrooke, Québec, Canada 2003.

Walsh, C., Roy, A., Feminella, J., Cottingham, P., Groffman, P. \& Morgan, R. (2005). The urban stream syndrome: Current knowledge and the search for a cure. Journal of the North American Benthological Society, 24(3), 706 - 723.

Xenopoulos, M., \& Schindler, D. (2001). The environmental controls of near-surface thermo-clines in boreal lakes. Ecosystems, 4, $699-707$.

Xie, D., \& James, W. (1994). Modelling solar thermal enrichment of urban stormwater. Journal of Water Management Modeling, 176, 13.

Zhou, Z., Smith, J. A., Yang, L., Baeck, M. L., Chaney, M., Ten Veldhuis, M. C., \& Liu, S. (2017). The complexities of urban flood response: Flood frequency analyses for the Charlotte metropolitan region. Water Resources Research, 53(8), 74017425.

Zoppou, C. (2000). Review of urban storm water models. Environmental Modelling \& Software, 16, 195 - 231. 